(C) 2020 by the Arizona Board of Regents on behalf of the University of Arizona. This is an Open Access article, distributed under the terms of the Creative Commons Attribution licence (http://creativecommons. org/licenses/by/4.0/), which permits unrestricted re-use, distribution, and reproduction in any medium, provided the original work is properly cited.

\title{
THE INTCAL20 NORTHERN HEMISPHERE RADIOCARBON AGE CALIBRATION CURVE (0-55 CAL kBP)
}

Paula J Reimer ${ }^{1 *}$ (D) - William E N Austin ${ }^{2,3} \cdot$ Edouard Bard $^{4, \dagger} \cdot$ Alex Bayliss $^{5}$ (i) $\bullet$

Paul G Blackwell ${ }^{6}$ - Christopher Bronk Ramsey ${ }^{7, \dagger}$ (10) Martin Butzin ${ }^{8, \ddagger}$ (1) Hai Cheng $^{9,10}$ • R Lawrence Edwards ${ }^{10,11} \cdot$ Michael Friedrich $^{12} \cdot$ Pieter M Grootes $^{13}$ •

Thomas P Guilderson ${ }^{14,15}$ • Irka Hajdas ${ }^{16, \dagger}$ (1) Timothy J Heaton ${ }^{6, \dagger}$ (i)

Alan G Hogg ${ }^{17, \dagger}$ (D) Konrad A Hughen ${ }^{18}$ (D) - Bernd Kromer ${ }^{19} \cdot$ Sturt W Manning $^{20}$ (i) •

Raimund Muscheler ${ }^{21, \dagger}$ (1) Jonathan G Palmer ${ }^{22}$ (1) Charlotte Pearson ${ }^{23}$ (1) •

Johannes van der Plicht ${ }^{24} \cdot$ Ron W Reimer $^{1} \cdot$ David A Richards ${ }^{25, \dagger} \cdot$ E Marian $\operatorname{Scott}^{26}$ -

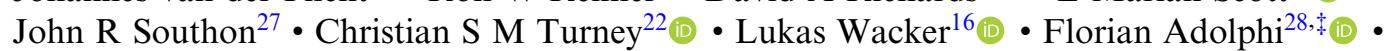

Ulf Büntgen $29,30,31,32, \$ \cdot$ Manuela Capano $4, \$$ (i) - Simon M Fahrni ${ }^{27,33, \$ \bullet}$

Alexandra Fogtmann-Schulz ${ }^{34, \$}$ - Ronny Friedrich ${ }^{35,+}$ • Peter Köhler ${ }^{8, \ddagger(i) ~ • ~}$

Sabrina Kudsk ${ }^{34, \ddagger} \cdot$ Fusa Miyake $36,+$ Jesper Olsen $^{37, \$} \cdot$ Frederick Reinig $^{30, \$} \bullet$

Minoru Sakamoto ${ }^{38, \ddagger} \cdot$ Adam Sookdeo $^{16,22, \ddagger} \cdot$ Sahra Talamo $^{39, \ddagger}$

${ }^{1}$ The ${ }^{14} \mathrm{CHRONO}$ Centre for Climate, the Environment and Chronology, School of Natural and Built Environment, Queen's University Belfast BT7 1NN, UK

${ }^{2}$ School of Geography \& Sustainable Development, University of St Andrews, St Andrews, KY16 9AL, UK

${ }^{3}$ Scottish Association for Marine Science, Scottish Marine Institute, Oban, PA37 1QA, UK

${ }^{4}$ CEREGE, Aix-Marseille University, CNRS, IRD, INRA, Collège de France, Technopôle de l'Arbois, Aix-en-Provence, France

${ }^{5}$ Historic England, 25 Dowgate Hill, London, EC4R 2YA UK

${ }^{6}$ School of Mathematics and Statistics, University of Sheffield, Sheffield S3 7RH, UK

${ }^{7}$ School of Archaeology, University of Oxford, 1 South Parks Road, Oxford OX1 3TG, UK

${ }^{8}$ Alfred-Wegener-Institut Helmholtz-Zentrum für Polar-und Meeresforschung (AWI), 27515 Bremerhaven, Germany

${ }^{9}$ Institute of Global Environmental Change, Xi'an Jiaotong University China, Xi'an, 710049, China

${ }^{10}$ Department of Earth and Environmental Sciences, University of Minnesota, Minneapolis, MN 55455-0231, USA

${ }^{11}$ School of Geography, Nanjing Normal University, Nanjing, China

${ }^{12}$ University of Hohenheim, Hohenheim Gardens (772), 70599 Stuttgart, Germany

${ }^{13}$ Institute for Ecosystem Research, Kiel University, Kiel, Germany

${ }^{14}$ Center for Accelerator Mass Spectrometry L-397, Lawrence Livermore National Laboratory, Livermore, CA 94550, USA

${ }^{15}$ Ocean Sciences Department, University of California - Santa Cruz, Santa Cruz, CA 95064, USA

${ }^{16}$ Laboratory of Ion Beam Physics, ETH, Otto-Stern-Weg 5, CH-8093 Zurich, Switzerland

${ }^{17}$ Radiocarbon Dating Laboratory, University of Waikato, Private Bag 3105, Hamilton, New Zealand

${ }^{18}$ Department of Marine Chemistry \& Geochemistry, Woods Hole Oceanographic Institution, Woods Hole, MA 02543, USA

${ }^{19}$ Institute of Environmental Physics, Heidelberg University, 69120 Heidelberg, Germany

${ }^{20}$ Cornell Tree Ring Laboratory, Cornell University, Ithaca, NY 14853, USA

${ }^{21}$ Quaternary Sciences, Department of Geology, Lund University, Sölvegatan 12, 22362 Lund, Sweden

${ }^{22}$ Chronos ${ }^{14}$ Carbon-Cycle Facility, the Changing Earth Research Centre, and School of Biological, Earth and Environmental Sciences, University of New South Wales, Sydney, NSW 2052, Australia

${ }^{23}$ The Laboratory of Tree-Ring Research, University of Arizona, Tucson AZ 85721-0400, USA

${ }^{24}$ Centrum voor Isotopen Onderzoek, Rijksuniversiteit Groningen, Nijenborgh 6, 9747 AG Groningen, Netherlands

${ }^{25}$ School of Geographical Sciences, University of Bristol, Bristol BS8 1SS, UK

${ }^{26}$ School of Mathematics and Statistics, University of Glasgow, Glasgow G12 8QS, Scotland

${ }^{27}$ Department of Earth System Science, University of California - Irvine, Irvine, CA 92697, USA

\footnotetext{
IntCal Focus group chair

*Guest contributor
} 
${ }^{28}$ Climate and Environmental Physics, Physics Institute \& Oeschger Centre for Climate Change Research, University of Bern, Sidlerstrasse 5, 3012 Bern, Switzerland

${ }^{29}$ Department of Geography, University of Cambridge, Cambridge CB2 3EN, UK

${ }^{30}$ Swiss Federal Research Institute (WSL), 8903 Birmensdorf, Switzerland

${ }^{31}$ Global Change Research Centre (CzechGlobe), 60300 Brno, Czech Republic

${ }^{32}$ Department of Geography, Faculty of Science, Masaryk University, 61300 Brno, Czech Republic

${ }^{33}$ Ionplus AG, 8953 Dietikon, Switzerland

${ }^{34}$ Department of Geoscience, Aarhus University, Høegh-Guldbergs Gade 2, 8000 Aarhus C, Denmark

${ }^{35}$ Curt-Engelhorn-Centre Archaeometry, Mannheim, Germany

${ }^{36}$ Institute for Space-Earth Environmental Research, Nagoya University, Nagoya, Japan

${ }^{37}$ Aarhus AMS Centre (AARAMS), Department of Physics and Astronomy, Aarhus University, Ny Munkegade 120, 8000 Aarhus C, Denmark

${ }^{38}$ National Museum of Japanese History, Sakura, Japan

${ }^{39}$ Dept. of Chemistry G. Ciamician, Alma Mater Studiorum, University of Bologna, Via Selmi 2, 40126 Bologna, Italy

ABSTRACT. Radiocarbon $\left({ }^{14} \mathrm{C}\right)$ ages cannot provide absolutely dated chronologies for archaeological or paleoenvironmental studies directly but must be converted to calendar age equivalents using a calibration curve compensating for fluctuations in atmospheric ${ }^{14} \mathrm{C}$ concentration. Although calibration curves are constructed from independently dated archives, they invariably require revision as new data become available and our understanding of the Earth system improves. In this volume the international ${ }^{14} \mathrm{C}$ calibration curves for both the Northern and Southern Hemispheres, as well as for the ocean surface layer, have been updated to include a wealth of new data and extended to $55,000 \mathrm{cal}$ BP. Based on tree rings, IntCal20 now extends as a fully atmospheric record to ca. $13,900 \mathrm{cal}$ BP. For the older part of the timescale, IntCal20 comprises statistically integrated evidence from floating tree-ring chronologies, lacustrine and marine sediments, speleothems, and corals. We utilized improved evaluation of the timescales and location variable ${ }^{14} \mathrm{C}$ offsets from the atmosphere (reservoir age, dead carbon fraction) for each dataset. New statistical methods have refined the structure of the calibration curves while maintaining a robust treatment of uncertainties in the ${ }^{14} \mathrm{C}$ ages, the calendar ages and other corrections. The inclusion of modeled marine reservoir ages derived from a three-dimensional ocean circulation model has allowed us to apply more appropriate reservoir corrections to the marine ${ }^{14} \mathrm{C}$ data rather than the previous use of constant regional offsets from the atmosphere. Here we provide an overview of the new and revised datasets and the associated methods used for the construction of the IntCal20 curve and explore potential regional offsets for treering data. We discuss the main differences with respect to the previous calibration curve, IntCal13, and some of the implications for archaeology and geosciences ranging from the recent past to the time of the extinction of the Neanderthals.

KEYWORDS: calibration curve, radiocarbon, IntCal20.

\section{INTRODUCTION}

In most radioactive isotope systems used for dating, a daughter product is available for measurement so that an absolute age can be calculated. Unfortunately, for radiocarbon $\left({ }^{14} \mathrm{C}\right)$ dating, this is not the case as the nitrogen produced by ${ }^{14} \mathrm{C}$ decay is not captured in most materials and, even if it were, this decay product would be swamped by the pervasive nature of nitrogen in the Earth system. Therefore, calibration against ${ }^{14} \mathrm{C}$ measurements from known-age or independently dated material is critical for providing a correction for changes in ${ }^{14} \mathrm{C}$ concentration within atmospheric and marine carbon reservoirs.

The IntCal Working Group (IWG) has endeavored to provide ${ }^{14} \mathrm{C}$ calibration curves at semi-regular intervals since 2004, building on pioneering work by Stuiver et al. (1986, 1998a). Each new curve release incorporated all calibration data available at the time of construction that met the IntCal criteria (Reimer et al. 2013a) using robust curve construction methods. Inevitably, new datasets and improved understanding of the natural fluctuations in ${ }^{14} \mathrm{C}$ in the atmosphere and oceans have resulted in an ongoing process of refinement, with curves (or particular datasets) becoming obsolete over time

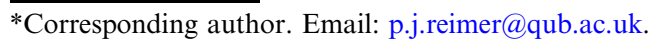



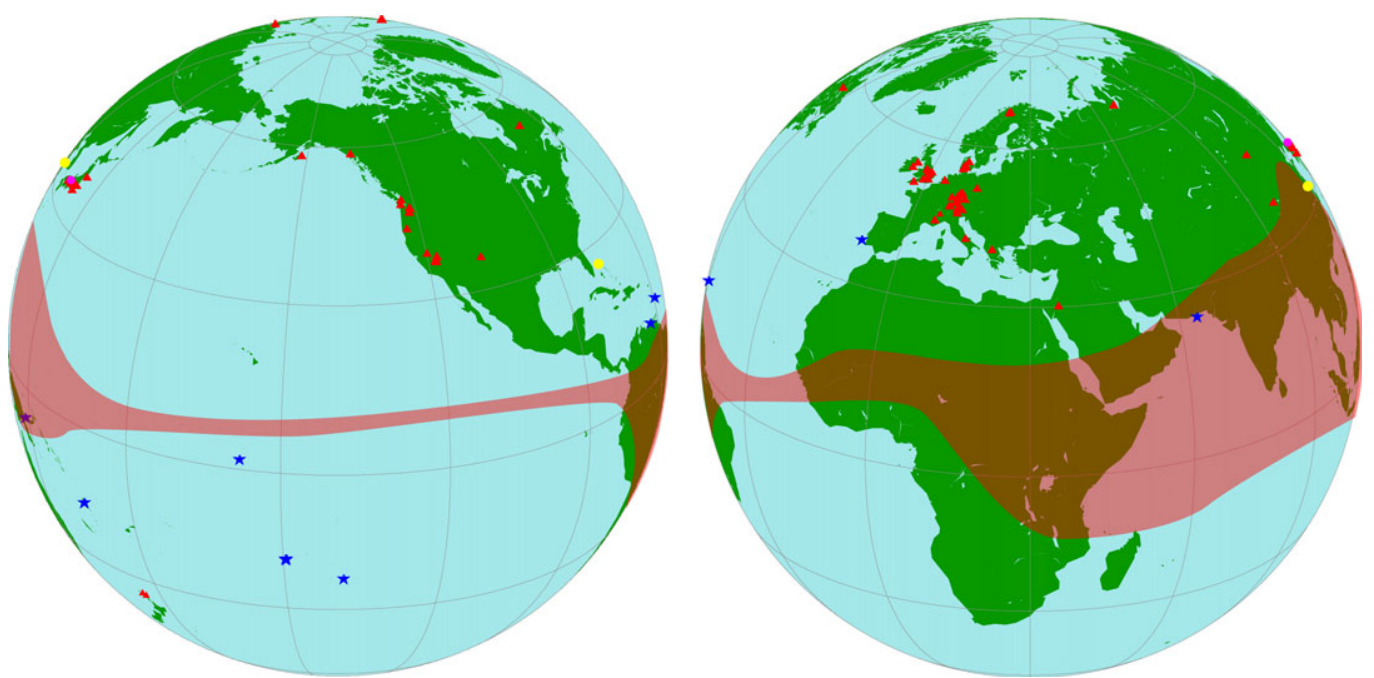

Figure 1 Global representation of the datasets included in the Northern Hemisphere IntCal20 calibration curve: tree rings (red triangles), marine (blue stars), speleothem (yellow circles), Lake Suigetsu (magenta circle). The extent of the Inter-Tropical Convergence Zone (ITCZ) is shown as a shaded band after the reconstruction of the zonal boundaries based on wind data Hogg et al. (2020 in this issue). (Please see electronic version for color figures.)

and replacement versions being released. In this latest iteration of the Northern Hemisphere IntCal curve, several new screening procedures were introduced to increase the transparency of data and metadata associated with a large influx of, mostly, annually resolved ${ }^{14} \mathrm{C}$ measurements from tree rings. Including the large number of these data points that meet the published IntCal criteria (Reimer et al. 2013a) and the additional screening procedures described below, allows for wider geographic coverage in the tree-ring datasets than in previous versions (Figure 1) and improves the data density, and thus robustness, of the calibration curve. Equally importantly, the new approach makes subtle alterations to the shape of the curve for a more accurate representation of ${ }^{14} \mathrm{C}$ concentrations across selected time periods not previously possible using multiyear tree-ring samples (blocks). Beyond the last 12,310 years for which securely dated tree-ring data are available, annual and multiyear tree-ring data from floating sequences offer new ways to resolve and secure coarser-resolution paleoenvironmental sequences. Thus, back to ca. 13,910 cal BP, where sufficient, continuous ${ }^{14} \mathrm{C}$ measurements of tree-ring chronologies exist, IntCal20 is fully atmospheric. For the older part of the timescale it was decided that the revised and extended atmospheric Lake Suigetsu varved sediment macrofossil record still lacked sufficient corroboration to be used as a stand-alone atmospheric record. Thus, this part of IntCal20 comprises statistically integrated evidence from floating tree-ring chronologies, terrestrial macrofossils from lake sediments, foraminifera from marine sediments, speleothems, and corals, using improved evaluation of the time and location variable ${ }^{14} \mathrm{C}$ offsets from the atmosphere (reservoir ages, dead carbon fractions) for each dataset. All these data have been combined using a newly developed Bayesian spline approach which has been adapted to optimize the incorporation of a large number of annual tree rings.

IntCal20 is one of a collection of three calibration curves. IntCal20 is intended for the calibration of Northern Hemisphere atmospheric samples; SHCal20 the calibration of Southern Hemisphere atmospheric samples (Hogg et al. 2020 in this issue); and Marine20 
(with application of a local reservoir adjustment) the calibration of marine samples (Heaton et al. 2020a in this issue).

\section{THE DATASETS}

The IWG has compiled an extensive database of published and previously unpublished data for the construction of the new curves which is available at http://intcal.org. A list of the datasets included in the northern hemispheric curve and references for these datasets are given in Table S2. Some corrections to datasets included in previous IntCal curves have been made and are given here or in accompanying papers. The details of the datasets used for the Southern Hemisphere calibration curve SHCal20 and any special considerations are given in Hogg et al. (2020 in this issue). All ages in this paper and the database are reported relative to $\mathrm{AD} 1950$ (=0 $\mathrm{BP}$, before present). Conventional ${ }^{14} \mathrm{C}$ ages are given in units "BP" and calendar or calibrated ages as "cal BP" or cal kBP (thousands of calibrated years before present). Historical $\mathrm{AD} / \mathrm{BC}$ dates (without the year zero) are also used for known age events and dendrochronological dated wood in some cases. Further, all quoted uncertainties on values or offsets, e.g. $14 \pm 3{ }^{14} \mathrm{C} \mathrm{yr}$, refer to the $1 \sigma$ level.

\section{Terrestrial ${ }^{14} \mathrm{C}$ Archives and Considerations}

\section{Tree Rings}

Data criteria. A total of 220 tree-ring datasets from both published and previously unpublished sources were screened for possible inclusion in the IntCal20 curve for the Northern Hemisphere. Where possible, the research group that had produced each dataset was asked whether they considered their data suitable for inclusion in IntCal20. A number of datasets were either rejected at this stage (because of known problems with dendrochronology, the dissection of tree-ring series for ${ }^{14} \mathrm{C}$ dating, the laboratory measurement, or the extant laboratory archive), or reserved for comparison purposes (e.g. where laboratories considered that higher quality data was available for a particular time period, or a laboratory problem was suspected but is still under investigation).

Datasets were then assessed against the relevant published IntCal criteria (Reimer et al. 2013a):

1. Laboratory methodologies

a. Pretreatment is specified,

b. Evidence of background or blank correction is provided,

c. Details of uncertainty calculations are provided,

d. Data from relevant intercomparison exercises, known-age samples, or reproducibility with existing calibration datasets are provided.

In addition, all new data accepted into IntCal20 were required to include all quantifiable sources of uncertainty either through a laboratory error multiplier or additional variance.

All laboratories provided at least some information covering all these categories. Pretreatment was generally fully specified, but the level of detail of background or blank correction and uncertainty calculations varied greatly between laboratories. Approaches to replication also varied. Overall more than one measurement on the same cellulose preparation is available for ca. $10 \%$ of dated tree-ring samples, although more than $95 \%$ of these are 
intra-laboratory replicates undertaken by QL- (set 1) and ETH- (set 69). Whole-process intralaboratory replicates are available for only ca. 3\% of dated tree-ring samples, almost $60 \%$ of which were undertaken by UCIAMS- (set 8), although inter-laboratory replicates are available for another ca. 3\% (Usoskin et al. 2013; Bayliss et al. 2020 in this issue; A. Sookdeo, personal communication; Pearson et al. 2020 in this issue; Friedrich et al. 2020 in this issue).

2. Dendrochronology

a. Sample derives from a single tree,

b. Methodology used for dating is specified,

c. Details of ring(s) sampled in a particular tree are specified,

d. Cross-matching of tree ring-width series is fully documented,

e. Cross-dating of tree ring-width series is fully documented (including version of reference chronologies used),

f. Raw ring-widths are published or deposited in a secure publicly accessible archive.

The criteria were expanded for this iteration of the curve to include dendrochronologies derived from $\delta^{18} \mathrm{O}$ pattern matching. This can be used in the same way as ring-width dendrochronology to produce tree-ring sequences on a calendar timescale and tested using similar statistical criteria to those employed for traditional tree-ring dating (Nakai et al. 2018; Loader et al. 2019).

A concerted effort was made to gather the required information for every new dataset under consideration for IntCal20 (and we thank the many dendrochronologists from all around the world who resolved our queries). At this stage, a number of datasets were rejected either because the dendrochronology was considered to be insecure or the dissection of the tree-ring series for ${ }^{14} \mathrm{C}$ dating was problematic. Other datasets have been reserved for comparison purposes (when insufficient information on the dendrochronology was available to us). Generally, considerable confusion was caused by the use of Historical BC (without a year zero) and Astronomical BC (with a year zero) in different laboratories and by different tree-ring software packages. It is essential that the calendar scale used is clear.

At this stage a small number of amendments/corrections were made to datasets that had been included in IntCal13:

1. Inconsistencies in block definition (e.g. which rings were sampled) were identified for the Amstel Castle data (van der Plicht et al. 1995; dataset 4/2), which could not be resolved and so this dataset has been removed from IntCal20.

2. A small number of data points in the Heidelberg datasets have been corrected (dataset $5 / 5$, $\mathrm{n}=26$ ) or withdrawn (dataset $5 / 3, \mathrm{n}=5$ ). Duplicate data in dataset $5 / 4$ has been removed (see below).

3. In previous IntCal curves the Kodiak Island $(\mathrm{KI})$ tree ${ }^{14} \mathrm{C}$ data were corrected for a $14 \pm 3$ ${ }^{14} \mathrm{C}$ yr offset between a tree growing on Kodiak Island, Alaska (dataset 1/1) and Washington state (Stuiver and Braziunas 1998). However, in IntCal20 the dataset's scaled deviation and mean offset as estimated during screening (see below) did not flag this as being an outlier. This correction was therefore not applied in IntCal20. 
Because of the large amount of new data under consideration, particularly from 0 to 3000 cal $\mathrm{BP}$, a minimum length for datasets was adopted to allow a realistic assessment of their reliability against existing datasets (10 measurements for decadal samples, 15 for 5-ring samples, 20 for 3-ring samples or 100 for single-year data, if not replicated by a second laboratory). An exception to the dataset length requirement was made for short series from laboratories also producing long datasets that passed the screening requirements. Another exception was data from the ${ }^{14} \mathrm{C}$ spike events (Miyake et al. 2012, 2013) that had been replicated worldwide by numerous laboratories.

Twenty of the new datasets under consideration did not meet these length criteria and have been retained as comparison datasets. An unpublished dataset of three 10-ring samples of Irish oak from 3450-3470 cal BP (measured at the Center for Accelerator Mass Spectrometry, Lawrence Livermore National Laboratory) that was included in IntCal13, was also too short and redundant with all the new single-year measurements in the same time period (e.g. Pearson et al. 2018, 2020 in this issue).

As a primary screening exercise, a preliminary curve was estimated using all the data under initial consideration. For each ${ }^{14} \mathrm{C}$ constituent dataset the scaled deviation (consisting of the sum of the scaled residuals) and the mean offset from this preliminary curve were calculated. This highlighted data which indicated potential inconsistencies relative to the other datasets and required further consideration. For those datasets with large scaled deviations (as assessed by a p-value) and high mean offsets, the authors were contacted and in most cases indicated there was a problem with the measurements that had not been resolved; hence these data are not included.

After this initial stage of screening, the process was repeated whereby another preliminary curve was created, but without those datasets excluded by the first screening. The p-values for the scaled deviations and mean residuals were re-calculated flagging up datasets that needed further individual consideration by the group. This was performed by visual inspection of plots and discussion within the group ending with a vote on inclusion. Data which were judged to be too scattered were excluded from the curve including Irish oak data published by McCormac et al. (2008; dataset 2/6), which had been included in IntCal09 and IntCal13.

Two further categories of data were excluded from IntCal20: (1) a small number of recent datasets which appeared to be depleted in ${ }^{14} \mathrm{C}$ resulting from the use of fossil fuels during the industrial revolution (Tans et al. 1979), and (2) datasets within or at the present day limit of the Inter-tropical Convergence Zone (ITCZ, see below). An inter-laboratory treering dating comparison led by L. Wacker was organized by the IntCal Dendrochronology focus group. The anonymized results of this comparison are presented in Wacker et al. (2020 in this issue) and provide insights into the accuracy and quality of high-precision measurements on single tree rings performed by the participating AMS laboratories. The Holocene measurements obtained by AMS are comparable in quality to the ones previously performed by decay counting (Stuiver et al. 1998a), though requiring several orders of magnitude less material, whereas during the late glacial (ca. 15-11.7 cal kBP), AMS measurements in IntCal20 are superior to previous decay counting results (Sookdeo et al. 2019 in this issue). As with previous calibration curves, some of the tree-ring datasets included in the curve are more variable than the quoted uncertainties would indicate i.e. ${ }^{14} \mathrm{C}$ determinations arising from tree rings with identical calendar years appear more 
widely spread than would be supported by their reported uncertainties. We call this additional variability over-dispersion. Rather than include a laboratory error multiplier as was done in the past, an additive error to correct for potential over-dispersion in the IntCal20 measurements was built into the Bayesian statistical method (Heaton et al. 2020b in this issue). By specifically including such an additive term to model over-dispersion we aimed to correct not only for any potential under-reporting of laboratory measurement error within the IntCal20 datasets but also potential dispersion caused by intra-hemispheric locational offsets and other inter-tree variation. A prior probability distribution (hereafter prior) for the level of over-dispersion was formed based upon inter-lab variability of the same tree-ring samples produced for the Sixth International Radiocarbon Intercomparison (SIRI, Scott et al. 2017b). This prior was expected to be somewhat conservative for the IntCal20 data (i.e. indicate a greater level of over-dispersion) due to the much wider set of AMS laboratories participating in SIRI than used for IntCal20. However, due to the large volume of IntCal20 data, our posterior estimate for the over-dispersion is dominated by the high quality IntCal20 data themselves. The posterior estimate for the over-dispersion within the Northern Hemisphere IntCal20 datasets can be seen in Heaton et al. (2020b in this issue, Figure 5). Anticipating similar levels of over-dispersion amongst the ${ }^{14} \mathrm{C}$ determinations users wish to calibrate, to improve calibration accuracy, this posterior is incorporated into our published curve through the creation of predictive intervals.

Consideration of regional and seasonal growth offsets in tree-ring ${ }^{14} \mathrm{C}$. While ${ }^{14} \mathrm{C}$ offsets between the Southern and Northern Hemispheres are well documented (McCormac et al. 1998; Stuiver and Braziunas 1998; Hogg et al. 2009; Turney et al. 2016a), offsets within the Northern Hemisphere are less well understood. Intrahemispheric offsets were predicted by a global tracer transport model using ocean boundary conditions (Braziunas et al. 1995) to be on the order of $8{ }^{14} \mathrm{C}$ yr or less in the Northern Hemisphere except at very high latitudes $\left(>70^{\circ} \mathrm{N}\right)$. However, offsets could also result, in theory, from the location of the tree relative to the ITCZ and monsoons, growing season differences, polar latitudes, proximity to upwelling of ${ }^{14} \mathrm{C}$-depleted ocean water, proximity to industrial centers, and high altitude. Regional offsets within a hemisphere can be difficult to corroborate, as they are of a scale similar to observed inter-laboratory variation (Wacker et al. 2020 in this issue; Friedrich et al. 2020 in this issue; Pearson et al. 2020 in this issue) but have been observed convincingly in a few cases (Turney et al. 2016a; Büntgen et al. 2018; Pearson et al. 2020 in this issue).

The ITCZ is an asymmetric area of low pressure around the thermal equator where the northeast and southeast trade winds converge. The ITCZ migrates on seasonal and longer timescales (Haug et al. 2001; Schneider et al. 2014). In extreme situations, the ITCZ appears to have experienced a major southward migration across Amazonia during Heinrich stadials (Cheng et al. 2013). Trees growing within the ITCZ are potentially subjected to air masses from different hemispheres at certain times of the year (Marsh et al. 2018; Hogg et al. 2020 in this issue). For example, Southern Hemisphere air masses in tropical and subtropical Brazil have been detected in ${ }^{14} \mathrm{C}$ measurements from trees growing in the 1960s (Lisi et al. 2001). Hua et al. (2004) similarly concluded that tropical trees from Thailand had lowered ${ }^{14} \mathrm{C}$ levels because of the influence of Southern Hemisphere air masses. The authors reported an offset of $32 \pm 8{ }^{14} \mathrm{C} \mathrm{yr}$ for pine from north-central Thailand compared to trees from the northwest United States (Stuiver et al. 1998b) between AD 1690 and 1780. However, this appears to be primarily an inter-laboratory 
effect, since the Thai data are younger than Tasmanian trees measured concurrently at the same laboratory (Hua et al. 2004) by $30 \pm 8{ }^{14} \mathrm{C}$ yr for AD 1620-1780 (data presented in Table 1 in Hogg et al. 2013a), which is identical to the interhemispheric offset for the same interval based on New Zealand cedar and British oak of $28-32 \pm 7{ }^{14} \mathrm{C} \mathrm{yr}$ (Hogg et al. 2002).

Tree-ring data from between or near the boundaries of the present day ITCZ (Figure 1) were therefore not included in IntCal20 but retained in the database for comparison. These include measurements from pine trees from Thailand obtained inside the ITCZ (Hua et al. 2004; Q. Hua, personal communication). In addition, a Tibetan juniper growing at $31^{\circ} \mathrm{N} 91^{\circ} \mathrm{E}$ (Büntgen et al. 2018), approximately at the northern boundary of the present day ITCZ, was not included because this dataset had a mean difference of $18.5{ }^{14} \mathrm{C}$ yr older compared to other IntCal datasets, which suggested a moderate influence of Southern Hemisphere air.

While altitude has been postulated as mechanism for increased ${ }^{14} \mathrm{C}$ in tree rings (Cain and Suess 1976), there is no evidence for this in more recent higher precision measurement of high elevation trees compared to low- and mid-elevation trees growing during ${ }^{14} \mathrm{C}$ spike events (Büntgen et al. 2018). However, altitude is a factor in growing season differences. Northern Hemisphere seasonal differences in ${ }^{14} \mathrm{C}$ between plants growing in the early spring and later in the summer can come about because stratospheric ${ }^{14} \mathrm{C}$ is injected into the troposphere during the boreal spring (Appenzeller et al. 1996; Stohl et al. 2003). For example, Dee et al. (2010) reported an offset of $19 \pm 5{ }^{14} \mathrm{C}$ yr between short-lived herbaria specimens collected in Egypt between AD 1700 and 1900 and IntCa109. Other studies using blocked (multiyear) tree-ring data have indicated that differences may be enhanced during periods of low solar activity when ${ }^{14} \mathrm{C}$ production is higher (Kromer et al. 2001). For example, Kromer et al. (2001) found only a minimal expected latitudinal offset between the ${ }^{14} \mathrm{C}$ ages of Turkish pines and German oak on average from AD 1420 and 1640 but the Turkish pines were older than the German oak by 17 years during the Spörer solar activity minimum. Dellinger et al. (2004) found deviations of up to $17 \pm 5{ }^{14} \mathrm{C} \mathrm{yr}$ for stone pine growing in the Alps between $3500 \mathrm{BC}$ and $3000 \mathrm{BC}$ compared to the low altitude tree-ring measurements that were included in IntCa198. Manning et al. (2018) also reported fluctuating regional offsets from AD 1610 to 1940 from trees growing in Jordan compared with IntCal13 averaging $19 \pm 3{ }^{14} \mathrm{C} \mathrm{yr}$, associated with periods of reversals and plateaus in the ${ }^{14} \mathrm{C}$ calibration record. However, this average offset is reduced to less than $10{ }^{14} \mathrm{C} \mathrm{yr}$ when compared to new datasets included in IntCal20 (L. Wacker, personal communication). Comparison of data from Germany and Turkey measured at the same laboratory-removing the issue of inter-laboratory variation as a cause-indicates similar fluctuating offsets in the period from the 17 th to the 8 th centuries $\mathrm{BC}$ that are again associated with reversals and plateaus in the ${ }^{14} \mathrm{C}$ calibration record (Manning et al. 2020).

While the mentioned examples may overestimate regional offsets, the large influx of annual tree-ring data submitted to IntCal20 offers a range of new approaches to study this issue. The results of a study of the global extent of cosmic events showed only slight differences between trees growing through a range of growth seasons across a range of environments during the years 774 and 993 AD and suggests only a slight latitudinal offset at these times (Büntgen et al. 2018: Fig. 3). Pearson et al. (2018) reported Irish oak latewood representing mid-May through early autumn growth (Baillie 1982) and North American bristlecone pine whole tree rings (representing June, July, August growth) which were within stated errors of one another in the period 1700-1500 BC. Pearson et al. (2020 in this issue) refine this to 
an average weighted mean difference of $-8.1 \pm 1.9{ }^{14} \mathrm{C}$ yr between Irish and North American ${ }^{14} \mathrm{C}$ data for this period. This is still within stated errors but may also reflect a slight latitudinal effect.

Future work on growing season differences and latitudinal dependences is therefore recommended along with exploration of other factors such as latitude or altitude. Seasonality will be particularly important for tracking and defining any new discoveries of rapid excursions in atmospheric ${ }^{14} \mathrm{C}$ concentration. For example, in the Southern Hemisphere, growth is split across two calendar years and for European oak, the earlywood is formed using photosynthates from the previous calendar year (Pilcher 1995). Either of these could potentially aid in refining the timing of rapid (intra- and inter-annual) events. In regions north of the polar front, atmospheric ${ }^{14} \mathrm{C}$ may be elevated in late spring/ early summer due to stratospheric injection of ${ }^{14} \mathrm{C}$ and therefore could, in theory, enrich the ${ }^{14} \mathrm{C}$ of trees growing north of the polar front. Stuiver and Braziunas (1998) found only a minimal $\Delta^{14} \mathrm{C}$ offset $\left(-0.3 \pm 0.7 \%\right.$ ) for $\mathrm{AD} 1615-1715$ but an offset of $26 \pm 6{ }^{14} \mathrm{C} \mathrm{yr}$ younger for $\mathrm{AD} 1545-1615$ for a Siberian larch tree $\left(67^{\circ} \mathrm{N}, 123^{\circ} \mathrm{E}\right)$ compared to a tree from Washington state $\left(48^{\circ} \mathrm{N}, 124^{\circ} \mathrm{W}\right)$ which is in good agreement with Büntgen et al. (2018). Data from northern Norway from trees growing during the peak of nuclear weapons testing also had higher ${ }^{14} \mathrm{C}$ (Hua and Barbetti 2007; Svarva et al. 2019) but may not be representative of natural offsets due to the high latitude of many of the atmospheric bomb tests. Büntgen et al. (2018) reported elevated ${ }^{14} \mathrm{C}$ values for some trees growing above $60^{\circ} \mathrm{N}$ at the peak of the AD 774/5 Miyake event (Miyake et al. 2012). The position of the present-day polar jet stream, which delineates the polar front, is presented as a latitudinal probability distribution by Molnos et al. (2017), but a simple boundary is not easily established. We therefore used $60^{\circ} \mathrm{N}$ for comparison of northerly trees with the other data. We found only small offsets for most tree ring ${ }^{14} \mathrm{C}$ data in the compilation above $60^{\circ} \mathrm{N}$ so retained the following datasets for use in the curve: SWE02 $\left(68.3^{\circ} \mathrm{N}, 19.6^{\circ} \mathrm{E}\right.$; dataset 69/34), Kom1213175a/b $\left(68.5^{\circ} \mathrm{N}, 20.0^{\circ} \mathrm{E}\right.$; dataset $\left.60 / 4\right)$, RUS04 $\left(67.5^{\circ} \mathrm{N}, 70.7^{\circ} \mathrm{E}\right.$; dataset $69 / 42)$, and Yamal $\left(67.5^{\circ} \mathrm{N}, 70.7^{\circ} \mathrm{E}\right.$; dataset $\left.68 / 8\right)$. Büntgen et al. (2018) reported offsets between $12 \pm 6$ and $27 \pm 5{ }^{14} \mathrm{C}$ yr younger for samples above $65^{\circ} \mathrm{N}$ measured at ETH. The potential for a latitudinal offset needs to be considered more carefully in the future.

Proximity to coasts with upwelling of older oceanic carbon has been proposed to cause ${ }^{14} \mathrm{C}$ offsets. As mentioned earlier, Stuiver and Braziunas (1998) found a $14 \pm 3{ }^{14} \mathrm{C}$ yr offset between a tree growing on Kodiak Island, Alaska (KI tree; dataset 1/1), and those trees growing in Washington State, USA. ${ }^{14} \mathrm{C}$ offsets between trees from Japan and the IntCal curves for several time periods have also been postulated to be due to ocean upwelling (e.g. Nakamura et al. 2007). It is not clear if these latter observations are real or a product of inter-laboratory variation.

To summarize, regional ${ }^{14} \mathrm{C}$ offsets can be difficult to determine due to measurement uncertainties and inter-laboratory offsets. Such analyses, however, are critical for future calibration curves, particularly to define the boundaries and changes through time of the ITCZ as well as growing season effects. ${ }^{14} \mathrm{C}$ measurements of tropical trees would provide much needed information on the ITCZ, however, it can be difficult to obtain reliable dendrochronological dates due to the limited seasonality in the tropics and subsequent indistinct tree rings. Through the application of X-ray densitometry and confirmation 
through ${ }^{14} \mathrm{C}$ measurements of trees growing during the nuclear weapons testing in the 1960s, chronology establishment was successful for some tropical species (Lisi et al. 2001; Santos et al. 2015). This may provide an improved understanding of the offsets because of the higher ${ }^{14} \mathrm{C}$ levels (Hua and Barbetti 2007).

Dataset updates. Irish oak data from the Waikato laboratory (Hogg et al. 2009) for the intervals AD 245-335, 745-785, and 895-935 had accidentally been left out of IntCal13 and are now included. Decadal German oak data from the Heidelberg laboratory for the period 1600-1700 BC were inadvertently entered twice with different laboratory ID's in IntCa109 and IntCal13. This problem was corrected for IntCal20.

From IntCa104 through IntCal13 (Reimer et al. 2004, 2009, 2013b), laboratory error multipliers for the tree-ring data were calculated from the offset with Seattle (QL) measurements with an estimated 1.3 error multiplier applied. Although no correction was made to the data for the calculated offset as had been done in IntCal98 (Stuiver et al. 1998a) the error multipliers increased the uncertainty in the data.

The Seattle error multiplier was re-calculated from replicates using equation 2 from Scott et al. (2017a). Of the replicates, 459 were duplicates, 35 were triplicates and there was 1 set each of quadruplets and quintuplets. The lab error multiplier $(\mathrm{k})$ was calculated to be 1.07 . Since the replicates were almost all aliquots of the same wood processed to alpha cellulose it was decided to leave the error multiplier at 1.3 which should encompass any additional variability such as a cellulose processing error. The laboratory error multipliers for the other legacy datasets were also left at the 2004 values with the exception of the more recent data from Belfast and Waikato where intra-laboratory multipliers had already been included in the reported uncertainties (McCormac et al. 2004; Hogg et al. 2009; datasets 2/1, 2/2, 3/1 and 3/2). The laboratory error multipliers for these datasets were therefore set to 1 in order not to apply the error multipliers twice.

A revised radon correction was applied to the Seattle data measured from 1977 to 1987 (Stuiver et al. 1998b). As an additional check on the revised radon correction, 10 decadal wood samples from a Douglas fir (S tree; dataset 1/10) from the Seattle laboratory were processed to cellulose by Fusa Miyake and measured by AMS in Belfast. Replicate AMS measurements on the cellulose were made on three samples to check potential outliers. The results of the new $\mathrm{S}$ tree cellulose extractions are within one standard deviation from the Seattle radon corrected measurements of the $\mathrm{S}$ tree and a sequoia ( $\mathrm{RC}$ tree) except for one sample at 995 cal BP (Figure S1; Table S1). These new replicate data have not been included in IntCal20.

Same cellulose replicates and processing error estimation. In order to avoid over-precise error estimates from averaging of replicates made on the same cellulose, a correction was made for cellulose processing differences. The cellulose processing error, in terms of $\Delta^{14} \mathrm{C}$, was estimated at $1 \%$ o $\left(1 \sigma\right.$; equivalently $8{ }^{14} \mathrm{C}$ yr $)(\mathrm{L}$. Wacker, personal communication) and may be even less for the large carbon mass samples used for radiometric dates. For replicates, identified by the same laboratory identification number, the cellulose processing uncertainty was removed from the total uncertainty by subtracting $8{ }^{14} \mathrm{C} \mathrm{yr}$ in quadrature. A weighted mean of the ${ }^{14} \mathrm{C}$ ages 
was calculated with the uncertainty in the mean given by $\sqrt{\frac{1}{\left(\frac{1}{\sigma_{1}^{2}}\right)+\left(\frac{1}{\sigma_{2}^{2}}\right)}}$ where $\sigma_{1}$ and $\sigma_{2}$ are the measurement uncertainties in the ${ }^{14} \mathrm{C}$ ages of the replicates. Finally, the cellulose processing error was added in quadrature to the uncertainty in the mean.

New measurements of single dendrochronologically dated tree rings. Publication of the rapid increase in atmospheric ${ }^{14} \mathrm{C}$ in $\mathrm{AD} 774-775$ (also known as the "Miyake event") and the subsequently discovered AD 993 event (Miyake et al. 2013) has prompted ${ }^{14} \mathrm{C}$ measurements on additional single tree rings from these time periods (e.g. Jull et al. 2014; Büntgen et al. 2018; Kudsk et al. 2019 in this issue) and led to the search for additional unusual events that can be detected in annual or biannual measurements (e.g. Miyake et al. 2017a, 2017b; Jull et al. 2018). To incorporate the large amount of annual data that have been produced for several of these short time periods and to represent the rapid increases, additional knots in the spline were included at these points for calibration curve construction (Heaton et al. 2020b in this issue).

Dating of the second millennium BC eruption of Thera (Santorini) has long been a contentious issue for Mediterranean archaeology. Bayesian models using the more recent iterations of IntCal have pointed to a late 17 th century $\mathrm{BC}$ eruption, contrary to some interpretations of the archaeological and historical evidence which indicate a more recent eruption date (Kutschera et al. 2012; Manning et al. 2014; and references therein). A recent publication of single-year bristlecone pine and Irish oak samples (Pearson et al. 2018) indicated that an annual calibration dataset might offer a new approach to this issue by refining the curve shape. IntCal13 was based on 20-, 10- and 5-ring samples of wood for this period and included a flat region or plateau. The annual calibration dataset has refined the definition of the plateau which is very important for establishing the true possible calendar age ranges for the key Theran datasets. Calibration models using a curve constructed in the same way as IntCal13 from the new bristlecone and oak data increased the probability of a more recent eruption (Pearson et al. 2018). To test these multispecies tree-ring data, a number of laboratories have now analyzed contemporary tree rings at annual resolution (Friedrich et al. 2020 in this issue; Kuitems et al. 2020 in this issue; Pearson et al. 2020 in this issue). All the new data for this time period that were available at the time of the curve construction have been included in IntCal20. Implications for the dating of the Thera eruption are discussed in light of the IntCal20 curve in Friedrich et al. (2020 in this issue), Pearson et al. (2020 in this issue), Kuitems et al. (2020 in this issue), and van der Plicht et al. (2020 in this issue).

The Hallstatt plateau (ca. 800-400 BC), one of the largest flatter regions in the calibration curve, has been problematic for resolving ${ }^{14} \mathrm{C}$ dating chronologies during a critical period in prehistorical technological developments in Europe and elsewhere without adequate stratigraphic control (Hamilton et al. 2015). Single-ring data from German oak and sequoia now provide detail for the first half of the Hallstatt plateau (2805-2575 cal BP) and increased the dating resolution across this key period (Park et al. 2017; Fahrni et al. 2020 in this issue).

Annual data for the period 290-486 AD (1660-1464 cal BP) (Friedrich et al. 2019) have also provided improved resolution of the IntCal raw data. These annual datasets demonstrate periodic changes in the annual records which may be attributed to the "11-year" Schwabe cycle (with a length from 9 to 11 years). They also show a ca. $20{ }^{14} \mathrm{C}$ yr offset from 
IntCal13 for a part of the time period covered, which is not explained by regional/latitudinal differences but more likely indicates that the curve could be slightly improved by more highly resolved data for a part of this period.

Floating tree-ring sequences: changes and additions. A major inter-comparison exercise using late glacial floating kauri tree-ring sequences (Hogg et al. 2016) resulted in a ${ }^{14} \mathrm{C}$ wiggle-match, with correction for the interhemispheric offset, to the European Preboreal Pine (PPC) chronology (Friedrich et al. 2004). This in turn indicated that the Swiss ZHYD-1 (formerly YD-B) record (Schaub et al. 2008; Hua et al. 2009; Kaiser et al. 2012) was incorrectly linked to the PPC. Tree-ring width reanalysis and annual resolution ${ }^{14} \mathrm{C}$ measurements between 13,150 and 11,800 cal BP of previously collected Swiss trees (Kromer et al. 2004; Schaub et al. 2008; Hua et al. 2009; Kaiser et al. 2012), as well as the recently discovered additional Swiss subfossil samples (Reinig et al. 2018), enabled the dendrochronological extension of the PPC (Reinig et al. 2020 in this issue), which is supported by ${ }^{14} \mathrm{C}$ wigglematching (Sookdeo et al. 2019 in this issue). The new PPC extension was then used to more securely wiggle-match the floating kauri chronology (Hogg et al. 2016) which in turn was used to reposition ZHYD-1 and the German/Swiss Central European Lateglacial Master Chronology (CELM) record (A. Sookdeo, personal communication) thus extending it to $14,226 \pm 4$ cal BP. However, the last few decades of this chronology could not be sampled for ${ }^{14} \mathrm{C}$ measurements. This new positioning was reinforced by the inclusion of single-year measurements of subfossil pine trees from the French Alps (Capano et al. 2018, 2019 in this issue) which strengthen the curve for this period.

Complementing the above, Adolphi et al. (2017) correlated three floating tree-ring chronologies from Northern Italy to ice core ${ }^{10} \mathrm{Be}$ datasets for the Bølling chronozone (ca. 14,700-14,000 cal BP, equivalent to GI-1e ${ }^{1}$ ) which indicated that the IntCall3 curve was too smooth in this period. We have incorporated these datasets but matched to the ${ }^{14} \mathrm{C}$ of the rest of the calibration data rather than using the ice core ages to keep the timescales independent (Muscheler et al. 2020 in this issue).

Further back in time, a 2000-yr-long series of bidecadal measurements of a floating kauri treering chronology spanning Heinrich Stadial 3 (ca. 30.6-28.9 cal kBP, equivalent to GS-5) from Finlayson Farm, New Zealand (Turney et al. 2016b) were ${ }^{14} \mathrm{C}$ matched to the other calibration datasets by including an interhemispheric offset $43 \pm 23{ }^{14} \mathrm{C}$ yr (Hogg et al. 2013b). These measurements provide added detail to the curve for HS-3/GS-5. A 1300-yr-long series on consecutive 100-ring samples from trees from Mangawhai Heads, New Zealand (Turney et al. 2010) was also included and is discussed in Muscheler et al. (2020 in this issue).

\section{Plant Macrofossils}

Plant macrofossils provide another possible sample type for calibration. The four characteristics to be considered in their application are (1) the reservoir from which their carbon originates, (2) the time period covered by their growth, (3) their preservation, and (4) the ability to provide an independent timescale. For atmospheric calibration this implies that the plant macrofossils should be from terrestrial rather than lacustrine or marine plant species and that they should either be from short-lived species or from annual growth of longer-lived species (leaves, needles and small twigs).

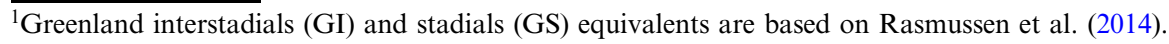


The preservation of such material is poor in many contexts but the anoxic conditions in some lake sediments allows for their preservation in a sufficiently good state for identification, and in sufficient density to provide a quasi-continuous record. Fortunately, such anoxic conditions, with minimal bioturbation can also result in annual layers or varves, which may additionally provide a (normally relative) independent timescale.

However, even in ideal circumstances, plant macrofossils do not allow the density of measurements, or the ability to undertake duplicate or high precision analyses that are afforded by tree rings. For this reason, although they do, like wood, provide a very direct measure of carbon in the atmosphere, they are only really useful for calibration in periods where wood is not available, or to provide a long-term record which spans a much longer timescale than any individual tree-ring series can. These considerations, along with the combination of criteria needed to make plant macrofossils a suitable material for ${ }^{14} \mathrm{C}$ calibration, make suitable records very rare and only the Lake Suigetsu varved sediment macrofossil data (Bronk Ramsey et al. 2012) is included in the IntCal20 curve. It is useful because it provides the only quasi-continuous, truly atmospheric record older than ca. $14,190 \mathrm{cal} \mathrm{BP}$, extending to the limit of the technique. This record has been reanalyzed with an extension and revision of the varve counting through to $50 \mathrm{cal} \mathrm{kBP}$ (Schlolaut et al. 2018). An updated timescale was modeled (Bronk Ramsey et al. 2020 in this issue) using both the new varve chronology and a ${ }^{14} \mathrm{C}$ wiggle-match to the extended Hulu Cave record (Cheng et al. 2018).

\section{Speleothems}

Speleothems are secondary carbonate mineral deposits formed in caves. Carbon, and hence ${ }^{14} \mathrm{C}$, in pristine calcite speleothems is derived from a variety of sources with a spectrum of ${ }^{14} \mathrm{C}$ ages. In simplest terms, these are atmosphere, soil gas, soil organic matter and ancient limestone, the last of which is essentially devoid of ${ }^{14} \mathrm{C}$ and contributes to the dead carbon fraction (DCF; for a recent review see Markowska et al. 2019). The relative contributions of different carbon pools to speleothem calcite (or aragonite) is site-specific and depends on many factors in the karst geochemical setting that respond to changing local climate and vegetation. Controlling factors of DCF include the extent of open or closed system dissolution of the host rock (Hendy 1971), the spectrum of ages of soil organic matter (Fohlmeister et al. 2011; Noronha et al. 2015), and influence of non-carbonic acids such as sulfuric acid (Bajo et al. 2017). Secular DCF variation is expected and numerous studies have indicated abrupt short-term variations related to climate change (e.g. Oster et al. 2010; Rudzka et al. 2011; Lechleitner et al. 2016), but the relative shifts are difficult to predict. To accommodate this, speleothem DCFs were modeled here as independent fluctuations around a constant mean. We placed a prior on the mean DCF for each speleothem based upon the period of speleothem growth that overlaps with tree ring records included in IntCal20 (Heaton et al. 2020b in this issue). This overlap additionally provided an estimate of the size of the independent fluctuations around this mean over time. During curve construction we further updated these prior mean DCF values to resolve potential offsets between datasets and obtain posterior DCF estimates for each speleothem.

The Hulu Cave H82 speleothem ${ }^{14} \mathrm{C}$ record was utilized in $\mathrm{IntCal13}$ from the end of the tree ring record at 14,153 cal BP to 26,850 cal BP (Southon et al. 2012). Recent ${ }^{14} \mathrm{C}$ and U-Th measurements on the Hulu Cave MSD and MSL speleothems overlap with the earlier measurements and provide new data to 53.9 cal kBP (Cheng et al. 2018). These speleothems were formed in a region of the cave underlying a portion of host rock for 
which the original limestone has been largely replaced with iron oxides (not sandstone as originally reported by Cheng et al. 2018). Speleothem DCF is predicted to be low and, most critically, show only minor variation (Cheng et al. 2018) because the waters derive most of their dissolved inorganic carbon from soil $\mathrm{CO}_{2}$ and the lower sections of the vadose pathway, dominated by Fe-oxides, and see minimal contribution from deep-seated soil-organic matter derived $\mathrm{CO}_{2} \cdot \delta^{13} \mathrm{C}$ values of these $\mathrm{Hulu}$ Cave stalagmites vary by several per mil (Kong et al. 2005). Notably, however, significant shifts in $\delta^{13} \mathrm{C}$ do not result in resolvable shifts in DCF (Southon et al. 2012). This decoupling can be explained by the fact that of the many well-known processes that control $\delta^{13} \mathrm{C}$ (Hendy 1971), a significant subset would not be expected to directly affect DCF. The latter includes shifts in overlying vegetation between $\mathrm{C} 3$ and $\mathrm{C} 4$ biomes, which is indeed invoked by Kong et al. (2005) to explain the $\delta^{13} \mathrm{C}$ variations observed at Hulu. In addition, the lack of nuclear weapons testing ${ }^{14} \mathrm{C}$ in the cave dripwaters, as well as observed seasonal $\delta^{18} \mathrm{O}$ values, support a relatively short residence time of the soil carbon and infiltration into the cave (Cheng et al. 2018).

Each Hulu Cave speleothem was permitted to have a potentially different DCF for the purposes of curve construction. A mean DCF value of $480 \pm 8{ }^{14} \mathrm{C}$ yr was used as a prior for each, with a further independent variation around this mean value in any particular calendar year of $\pm 50{ }^{14} \mathrm{C} \mathrm{yr}$, based upon calculations from the overlap of $\mathrm{H} 82$ with the updated tree ring section of the IntCal20 curves. The slight difference from the DCF value, in any calendar year, of $450 \pm 70{ }^{14} \mathrm{C}$ yr used by Cheng et al. (2018) is due to improvements in the tree-ring chronologies and additional measurements discussed above. During curve construction, these DCF priors were updated and we obtained posterior DCF estimates of $472 \pm 50{ }^{14} \mathrm{C} \mathrm{yr}$ for $\mathrm{H} 82,470 \pm 50{ }^{14} \mathrm{C} \mathrm{yr}$ for MSD, and $481 \pm 50{ }^{14} \mathrm{C} \mathrm{yr}$ for MSL respectively ${ }^{2}$. This demonstrates the DCF consistency across the three Hulu speleothems.

In addition, we utilize Bahamas speleothems which are represented in IntCal20 by two stalagmites collected in an underwater cave on Grand Bahama; GB89-24-1 (Beck et al. 2001) and GB89-25-3 (Hoffmann et al. 2010). The data from these speleothems were incorporated into IntCal13. GB89-25-3 was found broken with 4 basal pieces and 2 top pieces with an intermediate section being lost. Both samples exhibit growth that overlaps with tree ring sections to determine offset and uncertainty. Variation in DCF is greater than that observed in the Hulu speleothem H82. For GB89-24-1, the prior on the mean $\mathrm{DCF}$ value was $1515 \pm 32{ }^{14} \mathrm{C} \mathrm{yr}$, with an assumption of additional independent variation around this mean in any calendar year of $\pm 207{ }^{14} \mathrm{C}$ yr. This prior was updated during curve construction to provide a posterior DCF estimate for GB89-24-1 of $1523 \pm 208{ }^{14} \mathrm{C}$ yr. GB89-25-3 was treated as two separate sections. The prior for the mean DCF of the top sections was set at $2156 \pm 33{ }^{14} \mathrm{C} \mathrm{yr}$, with additional independent variation in any year of $\pm 319{ }^{14} \mathrm{C} \mathrm{yr}$, based on overlap with tree ring sections. After curve construction, the posterior DCF for these top sections was estimated to be $2173 \pm 320{ }^{14} \mathrm{C}$ yr. For the basal sections an uninformative prior on the mean DCF value was used allowing us to retain internal structure seen within this lower section but allow for a potential step change in DCF from the top sections. After curve construction, we obtained a posterior DCF for these basal section of $2891 \pm 323{ }^{14} \mathrm{C} \mathrm{yr}$ (Heaton et al. 2020b in this issue). The large DCF uncertainties downweight the contribution of the Bahama speleothem records to the calibration curve. However, their inclusion is justified because

\footnotetext{
${ }^{2}$ In reporting the $\pm 1 \sigma$ uncertainty for all DCF posteriors, we have subsumed the uncertainty in the posterior mean DCF level into the uncertainty due to additional independent variation.
} 


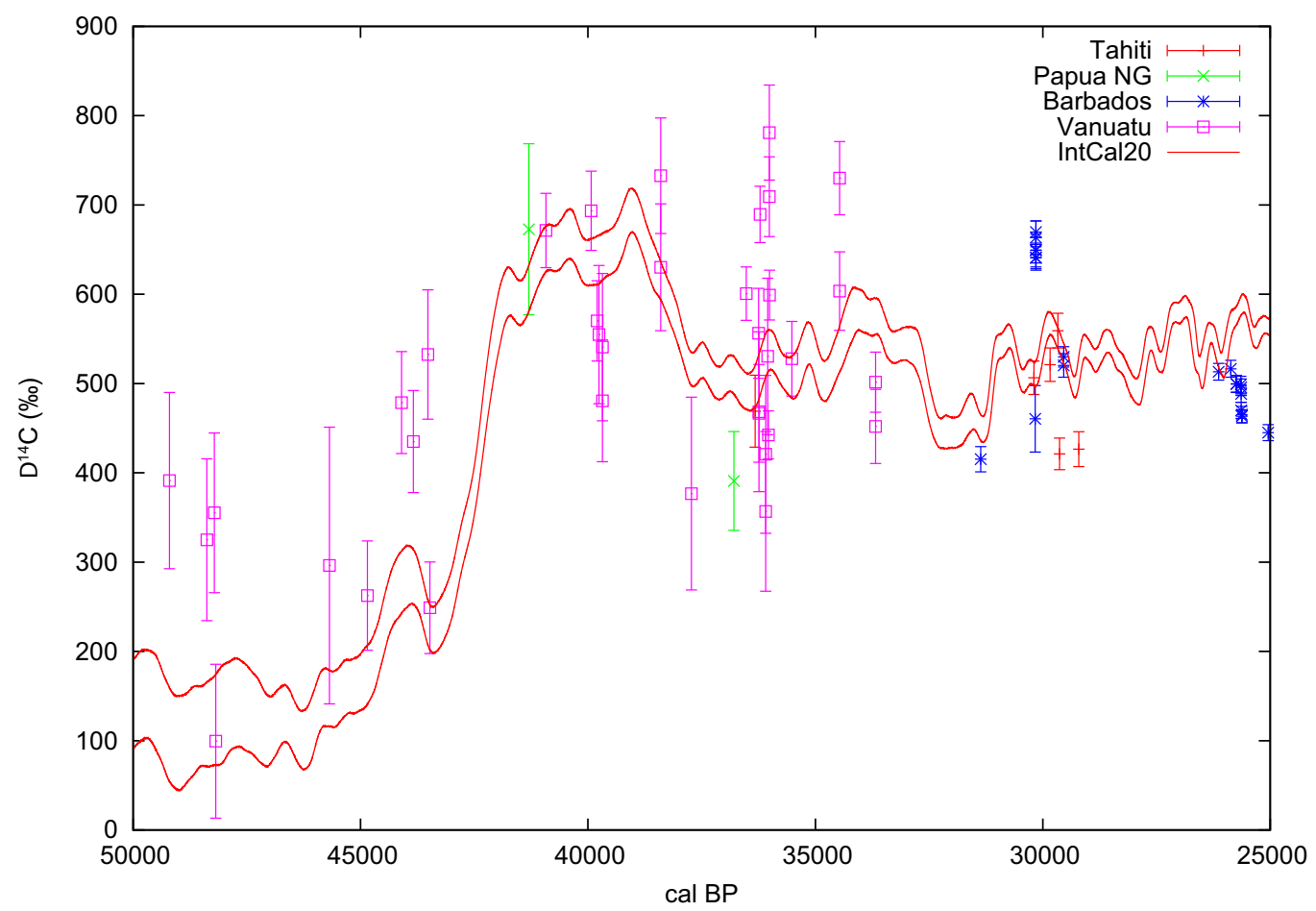

Figure 2 Age-corrected coral $\Delta^{14} \mathrm{C}$ older than $25 \mathrm{cal} \mathrm{kBP}$ from Bard et al. (1990, 1998, 2004a) and Durand et al. (2013) (Tahiti, Barbados, New Guinea), Cutler et al. (2004) (Vanuatu, Papua New Guinea) and Fairbanks et al. (2005) (Vanuatu, Barbados) compared to IntCal20 (shown with 1- $\sigma$ uncertainty envelope). The coral data is not reservoir corrected but this is not relevant for illustrating the large variation in the coral data.

the agreement between two speleothem records (e.g. Hulu Cave and Bahamas) with very different locations and depositional contexts builds increased confidence in both records as discussed in Southon et al. (2012).

\section{Marine ${ }^{14} \mathrm{C}$ Archives and Considerations}

There are no new U-Th dated coral ${ }^{14} \mathrm{C}$ measurements available prior to the Holocene since the publication of the IntCal13 and Marine13 curves (Reimer et al. 2013b). However, despite adhering to the IntCal criteria (Reimer et al. 2013a), some of the coral data used in IntCal13 exhibit wide scatter in $\Delta^{14} \mathrm{C}(\sim 500 \%$ ), especially around $37 \mathrm{kyr}$ BP (Figure 2). It is likely that diagenesis due to exposure to freshwater occurred when these corals were above sea level during the lowstand of the Last Glacial Maximum (LGM; $21 \pm 2 \mathrm{cal} \mathrm{kBP}$ ). This effect appears to have been particularly prevalent in corals from areas with rapid uplift such as Vanuatu for which coral $\Delta{ }^{14} \mathrm{C}$ appears very elevated $(>1100 \%$ around $27-29$ cal kBP; Cutler et al. 2004). In addition, a coral data point from Tahiti at $31 \mathrm{cal} \mathrm{kBP}$ is obviously an outlier as presented and discussed in Durand et al. (2013). It was therefore decided to remove all coral data older than $25 \mathrm{cal} \mathrm{kBP}$ for construction of the IntCal20 curves to avoid the potential inclusion of erroneous data. Further work is needed to develop a way of identifying which corals are affected by diagenesis.

As in IntCal13, the timescales for the marine foraminifera records from the Iberian margin, Pakistan margin and the Cariaco Basin were based on tie-pointing the rapid transitions 
between stadial and interstadial events in the proxy climate records, assumed to be synchronous within an uncertainty of $\pm 100 \mathrm{yr}$, to those in the Hulu Cave $\delta^{18} \mathrm{O}$ values (Wang et al. 2001; Cheng et al. 2016) using a Gaussian process model (Heaton et al. 2013). The assumption of synchronicity builds on our previous work focused on a few selected marine sites (see Hughen et al. 1996, 2004a, 2004b, 2006 for the Cariaco Basin; Bard et al. 2004a, 2004b for the Iberian Margin; and Bard et al. 2013 for the Pakistan Margin) and is supported by modeling results (e.g. Rind et al. 1986; Manabe and Stouffer 1995) showing tropical Atlantic and Asian responses to North Atlantic cooling, which suggests temporally rapid and spatially coherent changes across the area including the various climate archives.

For the sediment cores from the Pakistan and Iberian margins, the climate proxy records are the same as those described for IntCal13 (Bard et al. 2013). The only significant difference is that the Iberian alkenone-SST record has been remeasured to increase its time resolution and precision (Darfeuil et al. 2016), providing improved confidence in the correlation tie-points. In addition, the ${ }^{14} \mathrm{C}$ chronology of the Pakistan Margin record has been verified by analyzing different planktonic species of foraminifera (Fagault et al. 2019). A revision of the Cariaco Basin record tie-pointing and age-depth model has resulted in changes to the timescale used in IntCal13. The depth scale has been corrected as described in Hughen and Heaton (2020 in this issue) and the timescale recalculated.

\section{Marine ${ }^{14} \mathrm{C}$ Reservoir Ages}

Marine reservoir age (MRA) changes over time have long been recognized (e.g. Monge Soares 1993; Bard et al. 1994; Austin et al. 1995; Ingram 1998; Voelker et al. 1998) but have been difficult to quantify for many regions due to the lack of records with independent timescales. In previous versions of IntCal curves, site-specific MRA corrections were applied but these were assumed as constant through time, despite the knowledge that this was an overly simplistic approximation only. For example, it was well recognized that the atmospheric $\mathrm{pCO}_{2}$ minima during the LGM preserved in bubbles from Antarctic ice cores certainly contributed to an MRA increase of about $200{ }^{14} \mathrm{C}$ yr due to reduced atmospheric $\mathrm{CO}_{2}$ exchange with the ocean (Bard 1988; Galbraith et al. 2015). Changes in ocean circulation, such as the slowdown of the meridional overturning circulation during the last glacial (ca. 55-15 cal kBP) were likely responsible for additional increases in MRA (e.g. Stern and Lisiecki 2013; Skinner et al. 2017). For previous IntCal iterations, simple error multipliers for marine data were used partly to cover the possible time variations of the reservoir ages.

For IntCal20 it was decided to apply MRA corrections that vary both spatially and temporally. We use MRA fields calculated by means of an enhanced version of the Hamburg Large Scale Geostrophic Ocean General Circulation Model (LSG OGCM) (see Butzin et al. 2020 in this issue, and further references therein) driven by a preliminary atmospheric $\Delta^{14} \mathrm{C}$ reconstruction based on the Hulu Cave data alone. This preliminary atmospheric, Hulu-Cave-based, $\Delta^{14} \mathrm{C}$ estimate was obtained with the same Bayesian spline procedure used for IntCal20. Three scenarios of the LSG OGCM model were calculated using climatic boundary conditions, which were originally derived for the present day (PD) and the LGM (scenarios GS and CS). As described by Butzin et al. (2020 in this issue), the three scenarios aim at representing the effects of past ocean-climate variability on marine reservoir ages. Scenario PD approximates the Holocene and is also considered as a surrogate for interstadials. Scenario CS results in thermohaline ocean circulation properties characteristic of cold stadials (Sarnthein et al. 1994). The GS scenario was chosen for the data correction 


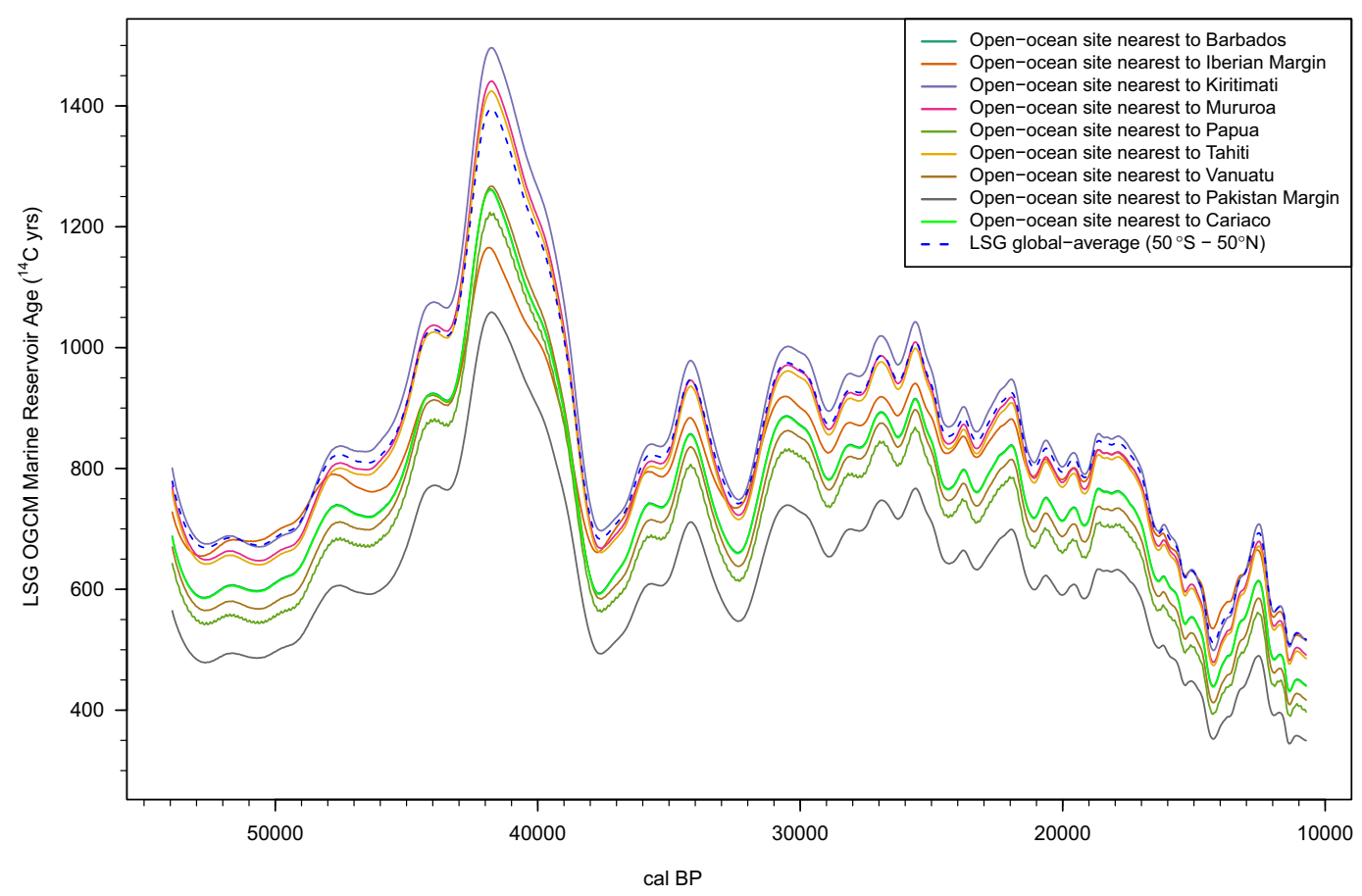

Figure 3 First-order regional open-ocean LSG OGCM MRA estimates based upon the LSG's Glacial Scenario (Butzin et al. 2017, 2020 in this issue) driven by a preliminary estimate of atmospheric $\Delta^{14} \mathrm{C}$ obtained from the Hulu cave speleothems alone. The plotted values correspond to the LSG site nearest the location of the marine IntCal20 datasets, the MRAs at the open-ocean sites nearest Barbados and Cariaco have almost indistinguishable plotted values. After application of a constant coastal adjustment, these MRAs are used as priors for the marine data in the creation of IntCal20. Note these Hulu-based estimates are intended solely to aid IntCal20 curve construction. In using Hulu Cave to force the LSG, we aim to provide a first-order approximation to the true regional MRAs which, after permitting some further MRA variability, enable the marine data to contribute to the IntCal20 curve. The plotted values are therefore only preliminary coarse approximations of the MRAs for the relevant locations and lack fine-scale structure.

because it can be considered as an approximation of the average climatic background conditions between 15 and 55 cal $\mathrm{kBP}$.

We obtained, under this GS scenario, Hulu-Cave-based MRA estimates for the LSG OGCM open-ocean site closest to the location of each marine dataset (Figure 3). These MRA estimates were expected to lack some fine scale features, as the Hulu-Cave-based $\Delta^{14} \mathrm{C}$ reconstruction is somewhat smoothed, yet still provide reliable first-order approximations. Since the IntCal20 marine data come from coastal, rather than open-ocean, sites we adjusted the corresponding nearest open-ocean LSG OGCM estimate by application of a constant coastal shift to obtain dataset-specific priors on the MRA for each marine dataset used in IntCal20. This shift aimed to correct for potential coastal effects not accounted for in the LSG OGCM model. Furthermore, to account for the overly smooth nature of these first-order Hulu-Cave-based MRA estimates we allowed additional independent fluctuations around these shifted estimates. Such an approach is analogous to that used to model the speleothem DCFs but, rather than assuming a constant mean, here we use the coastally shifted shape of the LSG OGCM estimates.

Equivalent to the speleothem DCFs, for each of the marine IntCa120 datasets, priors on the magnitude of the coastal shift needed and the size of the independent fluctuations around the 
Hulu-Cave-based first-order estimates were obtained from the observed ${ }^{14} \mathrm{C}$ offset between more recent marine samples from that location and overlapping IntCal20 Northern Hemisphere tree-ring data back to ca. 14,190 cal BP. See Heaton et al. (2020b in this issue) for further details and an illustration for Kiritimati. Our prior on the size of coastal shift needed from the open-ocean LSG OGCM estimates ranged from $12{ }^{14} \mathrm{C}$ yr for Vanuatu corals up to $281{ }^{14} \mathrm{C}$ yr for Kiritimati. For marine datasets for which we had no observations that overlapped with the Northern Hemisphere tree-ring data, the prior on the coastal shift was chosen to be non-informative while the estimate for the allowable fluctuations was taken from those for sites in the same oceanic region. This non-informative approach permitted us to retain the internal structure in these datasets. With the exception of the Cariaco basin, the resultant coastally shifted prior MRA estimates for each marine dataset were used as inputs for our Bayesian spline method of curve construction. During this process, again analogously to the approach taken to model speleothem DCFs, the constant coastal shift was further updated to resolve potential differences between datasets.

The estimated MRA using the above LSG OGCM based approach was, however, seen to be too high for Cariaco Basin data during the Younger Dryas (ca. 12.9-11.7 cal kBP) which corresponds to Greenland Stadial (GS-1), where it is known to be close to zero from the overlap with the tree rings, and likewise during Heinrich Stadial 1 (ca. 23-12.9 cal kBP, equivalent to GS-2) from comparison with the Hulu Cave data (Hughen and Heaton 2020 in this issue). The lack of fit of the LSG OGCM to Cariaco Basin MRA is not surprising given the model resolution of $\sim 380 \mathrm{~km}$ compared to the basin size of $160 \mathrm{~km}$ by $60 \mathrm{~km}$ (Butzin et al. 2020 in this issue) and the shallow sill depth (146 m at present) of the basin (Peterson et al. 2000). Instead, the MRA for Cariaco Basin was modeled as a slowly varying spline and estimated simultaneously to curve construction. Intuitively, this approach enabled the Cariaco data to offer support to the other IntCal20 datasets whereby ${ }^{14} \mathrm{C}$ variations seen in Cariaco data alone were likely to be assigned as MRA changes within the Cariaco basin and not propagate through to the final Intcal20 curve; while ${ }^{14} \mathrm{C}$ features seen not just in Cariaco but also other records would be more likely retained as genuine atmospheric signal (Heaton et al. 2020b in this issue). In IntCal09, the Cariaco Basin data for the Younger Dryas/GS-1 were excluded from consideration because the application of a constant marine reservoir offset caused an offset with the other data and likewise during HS-1/GS-2 in IntCal13 (Reimer et al. 2009, 2013b). With the modeled spline MRA and updated calendar age timescale for the non-varved record, the Cariaco Basin data from the Younger Dryas/GS-1 and HS-1/GS-2 are no longer offset from the rest of the data and are included in IntCal20. The climatic implications of the modeled reservoir age changes for Cariaco Basin data are discussed in Hughen and Heaton (2020 in this issue). It should also be noted that the modeled spline MRA for Cariaco Basin beyond the end of the Hulu Cave dataset was extrapolated to 55,000 cal BP to provide the final 1030 cal yr of the IntCal20 curve.

\section{CURVE CONSTRUCTION}

After the publication of IntCal13, the IWG determined the necessity of a statistically robust calibration curve construction method that could be run much more quickly than the Random Walk Model (Niu et al. 2013), so that different data options could be tested. Several Bayesian and frequentist methods (Kernel density, SIMEX, Bayesian spline) were examined by the IntCal statistics focus group who decided upon a Bayesian spline incorporating calendar age uncertainty (Berry et al. 2002; Heaton et al. 2020b in this issue). The quality of fit of 
the spline to the observed samples is based directly on ${ }^{14} \mathrm{C}$ determinations, while its smoothness is measured in the $\Delta^{14} \mathrm{C}$ domain. The Bayesian spline method has been refined in a number of ways that are specific to this application, for example to include an additive error term on the ${ }^{14} \mathrm{C}$ determinations to account for potential over-dispersion in observed ${ }^{14} \mathrm{C}$, to allow for the possibility of heavier-tailed errors on older data, and to explicitly recognise events involving rapid change in atmospheric ${ }^{14} \mathrm{C}$ (e.g. Miyake et al. 2012) in the structure of the curve (Heaton et al. 2020b in this issue).

\section{RESULTS}

Based on tree rings, IntCal20 extends to ca. 13,910 cal BP as a fully atmospheric record. The older part of IntCal20 comprises statistically integrated evidence from floating tree-ring chronologies, lacustrine and marine sediments, speleothems, and corals, using improved evaluation of the time and location variable ${ }^{14} \mathrm{C}$ offsets from the atmosphere (reservoir age, dead carbon fraction) for each dataset back to ca. 53,970 cal BP with MRA corrected Cariaco Basin data providing an extension to 55,000 cal BP. The IntCal20 calibration curve plotted with 1 standard deviation predictive envelopes over the full range of the calibration interval (0-55 cal kBP) in 2000-year intervals with all the datasets and uncertainties is provided in online Supplemental Material (Figure S2). These predictive intervals, and corresponding predictive uncertainties, incorporate the potential for overdispersion in a future $\mathrm{NH}$ atmospheric ${ }^{14} \mathrm{C}$ tree-ring measurement to be calibrated against the curve, i.e. that it too may be subject to some elements of additional intra-hemispheric variation beyond its quoted laboratory uncertainty. In incorporating this predictive element into the uncertainties on the final curve, it becomes more relevant for calibration users (Heaton et al. 2020b in this issue). The entire IntCal20 curve on a calendar grid providing both pointwise means and these predictive uncertainties is available to download at http:// intcal.org. IntCal20 contains significantly more fine structure prior to $33 \mathrm{cal} \mathrm{kBP}$ than the analogous portion of the IntCal13 curve. This is due to the increase in high resolution data and the improved statistical methods utilized and therefore should be more suitable for wiggle-matching than IntCal13 (Figure S3). The older portion of the IntCal20 curve also has a larger range in $\Delta^{14} \mathrm{C}$, with higher values than the highest IntCall3 values and lower values than the lowest IntCal13 values. The IntCal20 curve generally records higher $\Delta^{14} \mathrm{C}$ than IntCal13 between 33 and 42 cal $\mathrm{kBP}$ and lower $\Delta^{14} \mathrm{C}$ for times prior to $42 \mathrm{cal} \mathrm{kBP}$ (Figure 5).

\section{DISCUSSION}

A comparison of the IntCal20 and IntCal13 curves without the underlying data for clarity is given in Supplemental Material (Figure S3). Some of the main differences are described in more detail below.

\section{Rapid Excursions in Atmospheric ${ }^{14} \mathrm{C}$ in IntCal20}

A number of rapid increases in ${ }^{14} \mathrm{C}$ have recently been identified in annual data from calendar dated tree ring records. The AD 774-775 (1175-1176 cal BP) (Miyake et al. 2012) event is the most rapid and largest yet observed and is widely replicated (e.g. Büntgen et al. 2018) and is now considered to have been caused by an extreme solar proton event (Mekhaldi et al. 2015; Miyake et al. 2015). A second smaller event has been reported from AD 993 (957 cal BP) (Miyake et al. 2013) along with a number of other rapid ${ }^{14} \mathrm{C}$ increases of various scales and 

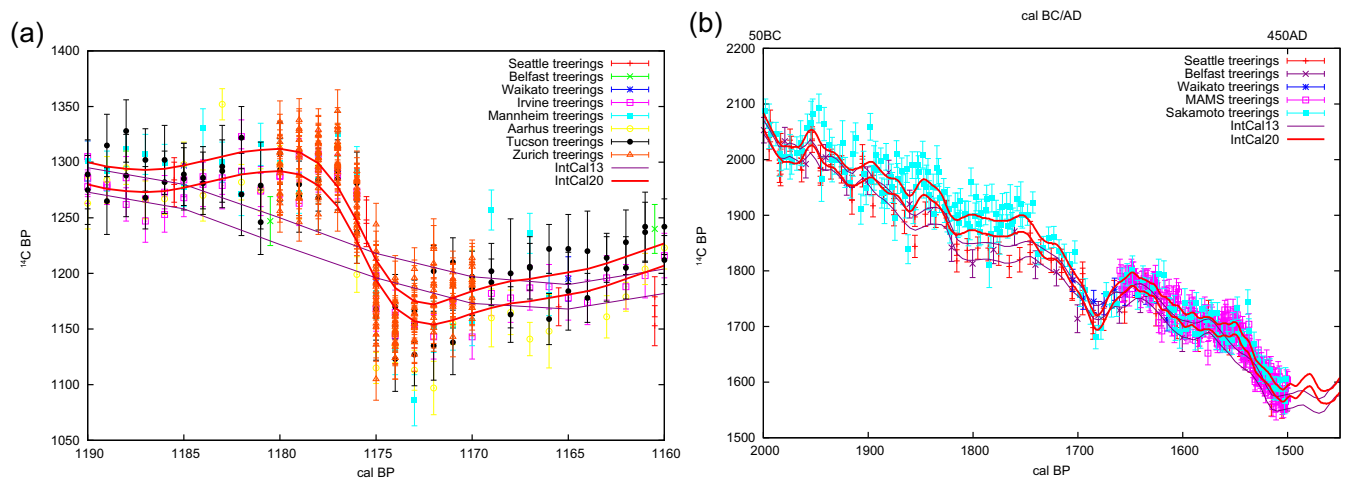

(c)

(d)
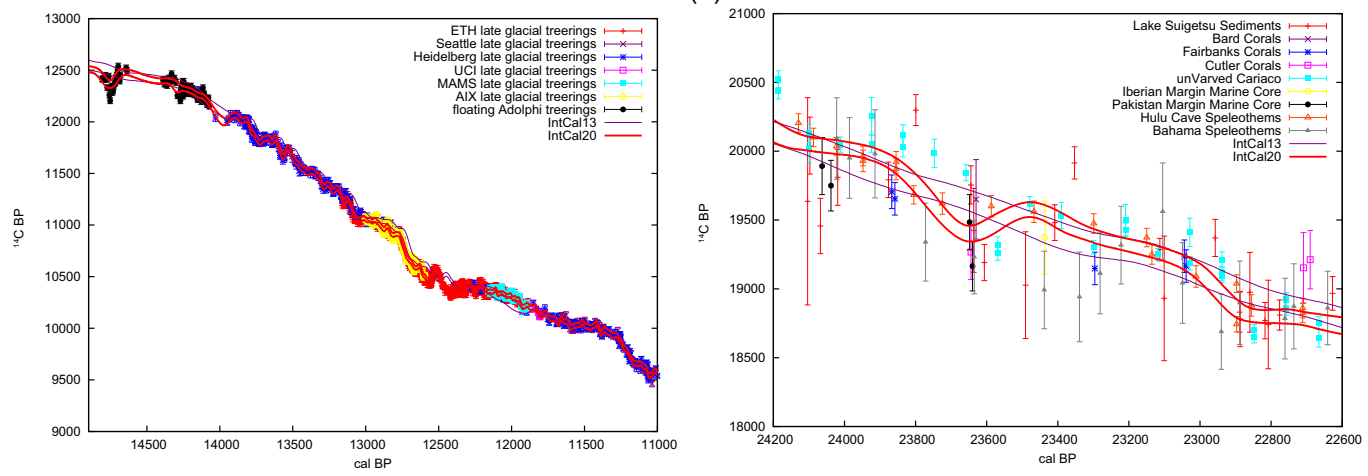

Figure 4 IntCal20 envelope ( $1 \sigma$ ) with data included for regions with large differences from IntCal13: (a) AD 774/5 Miyake event, (b) 1500-2000 cal BP, (c) 11,000-15,000 cal BP, and (d) 24.2-22.6 kcal BP. Data are shown with 1- $\sigma$ errors.

possible causes (e.g. Miyake et al. 2017a, 2017b; Jull et al. 2018; O'Hare et al. 2019). The AD 774-775 event is prominent in IntCal20 although the decline in ${ }^{14} \mathrm{C}$ age is smoothed out due to the time it takes for ${ }^{14} \mathrm{C}$ to mix into the ocean (Figure $4 \mathrm{a}$ ). This rapid ${ }^{14} \mathrm{C}$ increase will be particularly valuable for precise wiggle-matching sequences of ${ }^{14} \mathrm{C}$ ages (Wacker et al. 2014) to within 1-yr accuracy across this period. The other events discovered so far are less significant and consequently can only be used for precision wiggle-matching when the highest precision measurements are performed. Nevertheless, these structures revealed by tree ring annual ${ }^{14} \mathrm{C}$ are opening up a wide new range of potential for the synchronization of ice-core and tree-ring records and present new prospects and possibilities for precision dating.

\section{The Hallstatt Plateau}

At the beginning of the Hallstatt ${ }^{14} \mathrm{C}$ plateau just after $2700 \mathrm{cal} \mathrm{BP}$, the IntCal20 curve has a sharper dip in ${ }^{14} \mathrm{C}$ age than IntCal13 followed by a sharper rise and fall again around $2600 \mathrm{cal}$ BP (Figure S3). For the rest of the period the curve is generally similar to IntCal13 but with slightly more structure. The additional structure in the curve enhances the potential for wigglematch dating through the Hallstatt plateau which should be particularly valuable for archaeological studies. 


\section{2nd Millennium BP}

Larger differences to IntCal13 are seen between 2000-1700 cal BP (Figure 4b). These changes are due to the inclusion of measurements of Japanese tree rings; however immediately before and after this period, the Japanese tree rings are in agreement with European oaks and trees from the west coast of North America. These differences may be due to regional changes in the climate-carbon cycle that have not yet been identified.

\section{Late Glacial}

In the late glacial there is a shift to older calendar ages around $12.5 \mathrm{cal} \mathrm{kBP}$, primarily due to the new positioning of the tree ring crosslinks. The IntCal20 curve has more pronounced variations (wiggles) than IntCal13 because of the large amount of single-year data during this period. Floating tree-ring chronologies from Northern Italy provide structure to the curve for the Bølling (GI-1e) including a large trough around $14.8 \mathrm{cal} \mathrm{kBP}$ (Figure 4c). The ${ }^{14} \mathrm{C}$ trough appears slightly earlier than the abrupt rise in atmospheric $\mathrm{CO}_{2}$ at the start of Greenland Interstadial 1 that started around 14.6 cal $\mathrm{kBP}$ in the highly resolved West Antarctic Ice Sheet Divide ice core on its most recent age scale WD2014 (Marcott et al. 2014; Bauska et al. 2016; Sigl et al. 2016). Such pronounced variations in the calibration curve will result in wide calibration age ranges for single ${ }^{14} \mathrm{C}$ dates from this period as shown in Adolphi et al. (2017). There is also a pronounced wiggle around $23.6 \mathrm{cal} \mathrm{kBP}$, which is seen in many of the datasets (Figure 4d).

\section{Last Glacial}

There are many differences through the last glacial period to the end of the IntCal13 curve at 50 cal $\mathrm{kBP}$ with IntCal20 continuing to $55 \mathrm{cal} \mathrm{kBP}$ but with a wide error envelope. The changes beyond $30 \mathrm{cal} \mathrm{kBP}$ can be best observed in age-corrected $\Delta^{14} \mathrm{C}$ (Figure 5). In general, IntCal20 $\triangle^{14} \mathrm{C}$ is higher than IntCal13 from ca. $34-42 \mathrm{cal} \mathrm{kBP}$ and lower prior to this.

The IntCal20 $\Delta^{14} \mathrm{C}$ curve (Figure 5) concurs better with the amplitude of changes in the paleomagnetic and ${ }^{10} \mathrm{Be}$ records than IntCal13 (Laj et al. 2014; Laj and Kissel 2015; Muscheler et al. 2020 in this issue) and also agrees well with the independently dated Campagnian Ignimbrite (Giaccio et al. 2017). The rise in $\Delta^{14} \mathrm{C}$ in IntCal20 is coincident within dating uncertainties with the beginning of the Laschamp geomagnetic excursion as recorded in a Missouri stalagmite (Lascu et al. 2016). The highest $\Delta^{14} \mathrm{C}$ values in IntCal20 also correspond within dating uncertainties to the timing of the main phase of the Laschamp Event at $41.10 \pm 0.35 \mathrm{ka} \mathrm{BP}$ (Lascu et al. 2016) which is within $1 \sigma$ of the timing of the event in GLOPIS (Laj et al. 2014). These high values, however, continue on beyond the end of the Laschamp Event, likely, in part because of the long residence time (>1000 years) of carbon in the deep ocean and in part because of carbon cycle perturbations associated with Heinrich Stadial 4 (ca. 39.9-38.2 cal kBP, equivalent to GS-9), which postdate the Laschamp Event (Cheng et al. 2018). Small but resolvable peaks, which could correlate with the Mono Lake event, are evident in both IntCal20 and IntCal13.

The higher $\Delta^{14} \mathrm{C}$ values in IntCal20 from ca. 34-42 cal kBP means that the ages calibrated with IntCal20 may be up to 700 years older than with IntCal13 whereas from $42-50$ cal kBP the calibrated ages maybe more than 1000 years younger (Figure S3). The maximum ${ }^{14} \mathrm{C}$ age that can be calibrated with IntCal20 is 50,100 BP compared to 46,400 BP for IntCal13. 


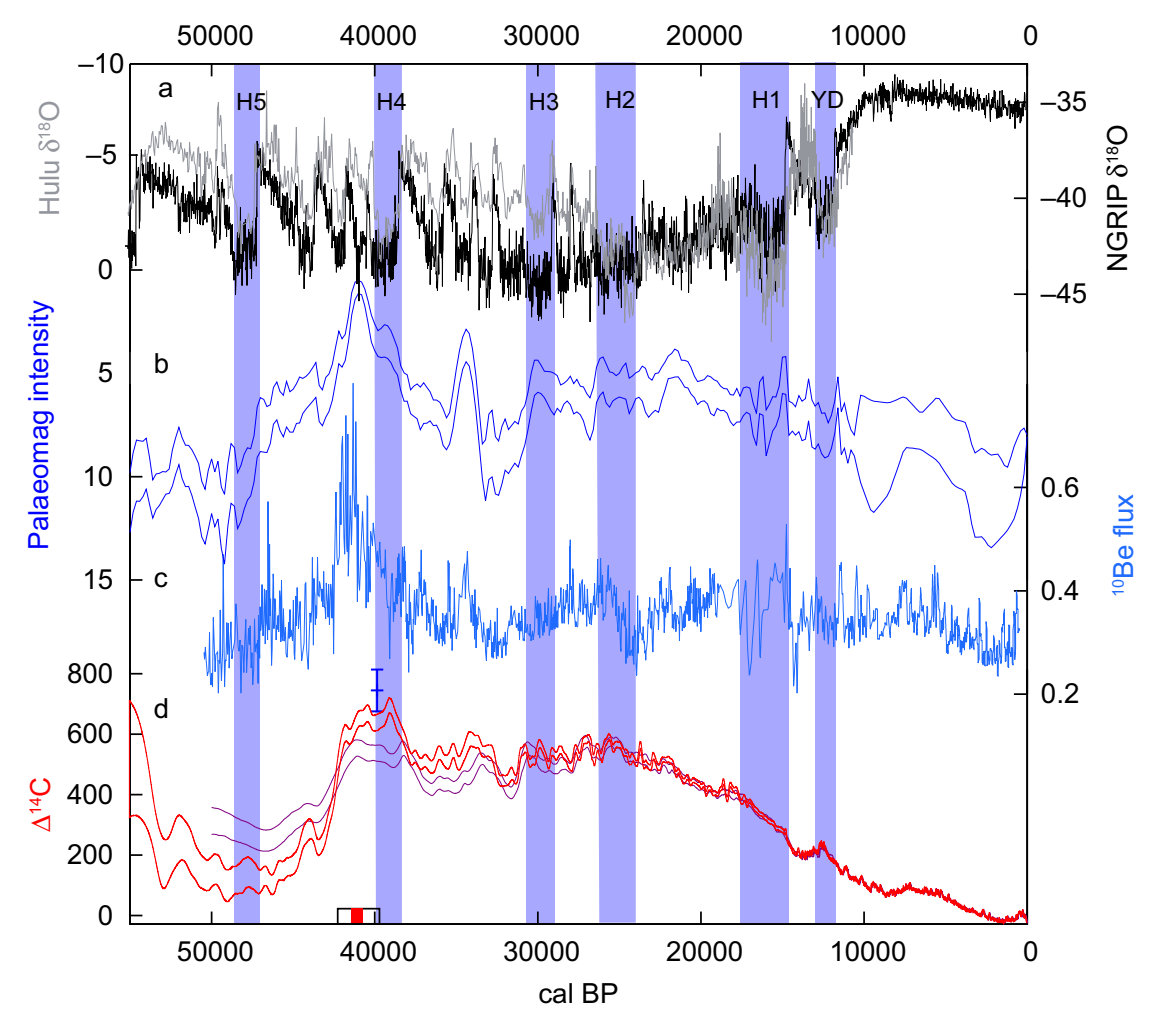

Figure 5 a) Hulu Cave $\delta^{18} \mathrm{O}$ (in gray, Cheng et al. 2016); NGRIP $\delta^{18} \mathrm{O}$ (in black, North Greenland Ice Core Project members 2004) with GICC05 timescale multiplied by 1.0063 as a first order correction to the offset between GICC05 and the West Antarctic Ice sheet (WAIS) Divide WD2014 chronology making it compatible with the Hulu Cave $\delta^{18} \mathrm{O}$ records (Buizert et al. 2015), b) GlOPIS-75 paleomagnetic stack (Laj et al. 2014; Laj and Kissel 2015), c) ${ }^{10} \mathrm{Be}$ flux (Muscheler et al. 2005). a-c on GICC05 timescale (Svensson et al. 2008) adjusted to 0 BP $=1950 \mathrm{AD}$, and d) IntCal20 (red) with IntCal13 (purple) as one sigma envelopes and the average for the Campagnian Ignimbrite (blue point, Giaccio et al. 2017). The duration of the Laschamps event is shown as an open box with the main phase shown as solid red (Lascu et al. 2016). Heinrich Stadials are shown in vertical bands with the timing and duration for H1, H3 and H4 taken from Waelbroeck et al. (2019) and references therein and that of H2 $(\mathrm{H} 2 \mathrm{a}+\mathrm{H} 2 \mathrm{~b})$ from the total organic carbon in Pakistan margin linked to the Hulu Cave timescale (Bard et al. 2013).

\section{CONCLUSIONS}

In summary, the main advances in the IntCal20 calibration curve are:

1. The inclusion of single-year tree-ring data for the late Holocene and the Younger Dryas/ GS-1, as well as floating tree chronologies for the Bølling/GI-1e and the last glacial period, means IntCal20 has considerably more detailed structure than previously provided in IntCal13;

2. The use of the Bayesian spline methodology in curve construction has allowed for predictive intervals for the curve that are able to account for over-dispersion seen within ${ }^{14} \mathrm{C}$ tree-ring determinations from the same calendar year; enabled the better representation of rapid events; as well as isolated real signals from noise, in many cases made possible through synchronizing fluctuations within their calendar age uncertainty; 
3. The incorporation of the LSG model MRA (Butzin et al. 2020 in this issue; Heaton et al. $2020 \mathrm{~b}$ in this issue) has resulted in convergence and better agreement between marine data and the other datasets;

4. The incorporation of new Hulu Cave data has allowed for the revision of the Suigetsu timescale and a curve extension to ca. 54 cal kBP (with Cariaco Basin data alone extending to $55 \mathrm{cal} \mathrm{kBP}$ ); and

5. The increased ${ }^{14} \mathrm{C}$ measuring precision allows detection of subtle regional and seasonal fluctuations in natural ${ }^{14} \mathrm{C}$ concentrations. These need to be considered in determining the overall uncertainty of a calibration using the global IntCal20 calibration.

\section{Implications for Archaeology and Earth Science}

The IntCal20 curve provides meaningful differences regarding the timing of the beginning and end of the Younger Dryas/GS-1 cold period in paleoenvironmental records. The increased details in the curve may lead to more complex, multimodal calibrated age probability distributions that may require stratigraphic information to resolve. These differences, as well as revisions to the calibration curve in the last glacial period, may have implications for the relative timing of ${ }^{14} \mathrm{C}$-dated environmental or archaeological records when these are compared to those on different timescales (e.g. ice core records). ${ }^{14} \mathrm{C}$ calibrations with IntCal20 will also differ from those with IntCal13 for almost all time periods prior to the late Holocene. This is an important consideration given even small changes in the curve can have a large effect on archaeological chronologies where Bayesian analysis is used to estimate time spans on the order of a human lifetime or less.

The higher-resolution data and revised positioning of some of the European tree-ring chronologies allows for more precise correlation of archaeological records to those on different timescales (e.g. ice core records).

Specific examples of the difference in calibrations with the IntCal13 and IntCal20 curves are provided in van der Plicht et al. (2020 in this issue).

\section{Future Directions}

The largest changes in the IntCal20 calibration curve are during the last glacial period, particularly older than 30 cal kBP. Because the older portion of the new curve is based directly or indirectly on the U-Th timescale, a transfer function to the ice core GICC05 timescale will be possible (Adolphi et al. 2018). This should allow better comparison between ${ }^{14} \mathrm{C}$ ages and paleoclimate records (Muscheler et al. 2020 in this issue). In addition, geomagnetic excursions may prove to be of increasing importance for aligning different ${ }^{14} \mathrm{C}$ datasets and ultimately correlation to ice core records via ${ }^{10} \mathrm{Be}$ (Muscheler et al. 2020 in this issue) or in marine sediments where the geomagnetic excursion is recorded in sediment component magnetization direction and its associated ${ }^{14} \mathrm{C}$ signature can be found in the same records, such as in Channell et al. (2016).

The use of a modeled MRA improved the fit of the current marine records with other datasets, helping identify true signals. We used the glacial scenario (GS) for our model MRA corrections for the marine data. In the future it may be possible to replace the Hulu-based ${ }^{14} \mathrm{C}$ curve by a truly atmospheric input as the driver and switch between scenarios within the Bayesian model 
based on climate proxies. Higher resolution models may also be able to resolve smaller regions of the ocean such as the Cariaco Basin (Butzin et al. 2020 in this issue).

Ultimately the IWG would hope to provide fully atmospheric curves for the Northern and Southern Hemispheres without reliance on more indirect records such as speleothems or marine data. In the absence of continuous dendrochronologically dated tree rings through the ${ }^{14} \mathrm{C}$ timescale, floating tree-ring series in combination with other time scales (e.g. linked via ${ }^{10} \mathrm{Be}$ to ice core time scales) hold the best possibility to improve the calibration curve in the future, using the other datasets as a backbone.

Single tree-ring measurements, covering over 3000 years across various time periods, from multi-region, securely dated, tree-ring chronologies have made a significant impact on this update of the curve, particularly in resolving rapid events and helping to understand their underlying processes. Given this demonstrated potential from both calendar dated and floating tree ring sequences and in anticipation of the inclusion of an even larger number of such data in future iterations of the calibration curve, the IntCal working group is developing a series of standardized procedures surrounding the creation and submission of such data. In addition to referencing previously published requirements for the submission of IntCal data (Reimer et al. 2013a) this includes extra steps to avoid any ambiguity when working with trees dated using the different methodological procedures necessitated by different species at different laboratories. For example, cross-checking on nomenclature used to assign dated years as astronomical dates (including a "year 0" $\mathrm{BC}$ ) or as $\mathrm{AD} / \mathrm{BC}$ with no zero year, and making sure there is a clear statement of this associated with the submitted data, metadata, dissected samples and remnant material (retained at the tree ring host institution). As for all IntCal data the aim is to move towards improved data stewardship and public archiving or open access in line with recent standards (Kaufman et al. 2018). By standardizing the criteria required for the preparation of tree-ring samples for annual ${ }^{14} \mathrm{C}$ analysis and the submission of these data and metadata to IntCal the aim is to ensure the very best compliance in open-data standards. The dendrochronological community has a data-standard (Jansma et al. 2010), a range of open-source tools (Tyers and Jansma 2011) and data repositories (e.g. the International Tree-Ring Data BankITRDB, and the Digital Collaboratory for Cultural Dendrochronology-DCCD; Jansma et al. 2012) but, because of the importance of full transparency with annual ${ }^{14} \mathrm{C}$ data for any IntCal submitted data, we now also require reports from the tree-ring laboratory in which the dendrochronological dating was carried out which include meta data, raw ring width or $\delta^{18} \mathrm{O}$ measurements and cross-correlation statistics. At present the IntCal20 database is not set up to make this collected information accessible, but future database development, perhaps utilizing the IntChron framework initiative (Bronk Ramsey et al. 2019) or partnering with the ITRDB, will address this pressing requirement.

The value of identifying more rapid ${ }^{14} \mathrm{C}$ events in the annual records from tree rings is hard to overstate. These features are of multidisciplinary significance. The potential of annual ${ }^{14} \mathrm{C}$ data to further refine what we know about regional, latitudinal or altitudinal differences in ${ }^{14} \mathrm{C}$ and to improve the shape of the calibration curve (particularly across transitional areas-from slopes to plateaus) has been explored but has opened up a whole new range of questions. In terms of calibration a more highly resolved curve shape produced by annually based data may be a more accurate representation of past ${ }^{14} \mathrm{C}$ variations but depending on final shape may actually result in multimodal probability distributions. While opportunities for high-resolution wiggle-matching may be increased for certain samples, precision may be 
decreased or multiple different possibilities returned for other scenarios. Comparison of annual data from contemporary tree rings analyzed at multiple laboratories should also be used to more fully explore issues of error and reproducibility between laboratories for such data and could be developed to better inform error estimations for Bayesian modeling for "annual" samples. In addition, with decreased measurement uncertainties it may be possible to check the assumption that the Northern Hemisphere atmosphere is well-mixed. This has already been questioned for some regions, but further laboratory intercomparisons are needed to ascertain whether differences seen between geographic regions are due to laboratory offsets or represent genuine offsets, the latter potentially requiring the development of region-specific calibration curves. Now that there is the capacity and capability available to measure large numbers of annual samples at sufficiently high precision (Capano et al. 2019 in this issue; Sookdeo et al. 2019 in this issue), these are likely to be important areas of research in the future.

\section{ACKNOWLEDGMENTS}

We are grateful to the dendrochronologists who provided information on the various trees including Christopher Baisan, Peter Brewer, David Frank and Irina Panyushkina (University of Arizona), David Brown (Queen's University Belfast), Claudia Baittinger (National Museum of Denmark), Esther Jansma (Stichting Nederlands Centrum voor Dendrochronologie), Kurt Nicolussi (Universität Innsbruck), Cathy Tyers (Historic England), Dominique Arseneault (Université du Québec), Bao Yang (Chinese Academy of Sciences), Paul Krusic (University of Cambridge), Mauro Bernabei (Italian National Research Council), Jan Esper (Johannes Gutenberg-Universität Mainz), Greg Wiles (The College of Wooster), Amy Hessl (West Virginia University), Rashit Hantemirov (Russian Academy of Sciences), Niels Bleicher (Center for Underwater Archaeology and Dendroarchaeology Zürich), Henri Grissino-Mayer (formerly of University of Tennessee), Neil Loader (University of Swansea), Takumi Mitsutani (Nara National Research Institute for Cultural Properties), Katsuhiko Kimura (Fukushima University), Takeshi Nakatsuka (Nagoya University), Masataka Hakozaki (National Museum of Japanese History), and Cécile Miramont, Lisa Shindo, Frédéric Guibal (Aix-Marseille University, Avignon University). We also acknowledge the many useful discussions with members of the IntCal focus groups and others in the scientific community. We thank Catherine Kissel and Carlo Laj for useful information about the GLOPIS curve and Darryl Granger for his insight into the geology of Hulu Cave. We also are grateful to Barbara Wohlfarth for the very thorough and constructive review.

We would like to thank the National Natural Science Foundation of China grants NSFC 41888101 and NSFC 41731174, the 111 program of China (D19002), U.S. NSF Grant 1702816, and the Malcolm H. Wiener Foundation for support for research that contributed to the IntCal20 curve. The work on the Swiss and German YD trees was funded by the German Science foundation and the Swiss National Foundation (grant number: 200021L_157187). The operation in Aix-en-Provence is funded by the EQUIPEX ASTERCEREGE, the Collège de France and the ANR project CARBOTRYDH (to EB). The work on the correlation of tree ring ${ }^{14} \mathrm{C}$ with ice core ${ }^{10} \mathrm{Be}$ was partially supported by the Swedish Research Council and the Knut and Alice Wallenberg foundation. M. Butzin was supported by the German Federal Ministry of Education and Research (BMBF) as Research for Sustainable Development (FONA; http://www.fona.de) through the PalMod project (grant number: 01LP1505B). S. Talamo and M. Friedrich are funded by the 
European Research Council under the European Union's Horizon 2020 Research and Innovation Programme (grant agreement No. 803147-RESOLUTION, awarded to ST). CA. Turney would like to acknowledge support of the Australian Research Council (FL100100195 and DP170104665). P. Reimer and W. Austin acknowledge the support of the UKRI Natural Environment Research Council (Grant NE/M004619/1). T.J. Heaton is supported by a Leverhulme Trust Fellowship RF-2019-14019. Other datasets and the IntCal20 database were created without external support through internal funding by the respective laboratories. We also would like to thank various institutions that provided funding or facilities for meetings.

\section{SUPPLEMENTARY MATERIAL}

To view supplementary material for this article, please visit https://doi.org/10.1017/RDC. 2020.41

\section{REFERENCES}

Adolphi F, Muscheler R, Friedrich M, Güttler D, Wacker L, Talamo S, Kromer B. 2017. Radiocarbon calibration uncertainties during the last deglaciation: Insights from new floating tree-ring chronologies. Quaternary Science Reviews 170:98-108.

Adolphi F, Bronk Ramsey C, Erhardt T, Edwards RL, Cheng H, Turney CS, Cooper A, Svensson A, Rasmussen SO, Fischer H. 2018. Connecting the Greenland ice-core and U/Th timescales via cosmogenic radionuclides: testing the synchroneity of Dansgaard-Oeschger events. Climate of the Past 14(11):1755-1781.

Appenzeller C, Holton JR, Rosenlof KH. 1996. Seasonal variation of mass transport across the tropopause. Journal of Geophysical ResearchAtmospheres 101(D10):15071-15078.

Austin WEN, Bard E, Hunt JB, Kroon D, Peacock JD. 1995. The ${ }^{14} \mathrm{C}$ age of the Icelandic Vedde ash: Implications for Younger-Dryas marine reservoir age corrections. Radiocarbon 37(1):53-62.

Baillie MGL. 1982. Tree-ring dating and archaeology. Chicago (IL): University of Chicago Press. p. $46-51$.

Bajo P, Borsato A, Drysdale R, Hua Q, Frisia S, Zanchetta G, Hellstrom J, Woodhead J. 2017. Stalagmite carbon isotopes and dead carbon proportion (DCP) in a near-closed-system situation: An interplay between sulphuric and carbonic acid dissolution. Geochimica et Cosmochimica Acta 210:208-227.

Bard E. 1988. Correction of accelerator mass spectrometry ${ }^{14} \mathrm{C}$ ages measured in planktonic foraminifera: paleoceanographic implications. Paleoceanography 3:635-645.

Bard E, Hamelin B, Fairbanks RG. 1990. U-Th ages obtained by mass-spectrometry in corals from Barbados-sea-level during the past 130,000 years. Nature 346:456-458.
Bard E, Arnold M, Mangerud J, Paterne M, Labeyrie L, Duprat J, Melieres MA, Sonstegaard E, Duplessy JC. 1994. The North-Atlantic atmosphere-sea surface C-14 gradient during the Younger Dryas Climatic Event. Earth and Planetary Science Letters 126(4):275-287.

Bard E, Arnold M, Hamelin B, Tisnerat-Laborde N, Cabioch G. 1998. Radiocarbon calibration by means of mass spectrometric ${ }^{230} \mathrm{Th} /{ }^{233} \mathrm{U}$ and ${ }^{14} \mathrm{C}$ ages of corals: An updated database including samples from Barbados, Mururoa and Tahiti. Radiocarbon 40(3):1085-1092.

Bard E, Rostek F, Ménot-Combes G. 2004a. Radiocarbon calibration beyond 20,000 B.P. by means of planktonic foraminifera of the Iberian Margin. Quaternary Research 61(2):204-214

Bard E, Ménot-Combes G, Rostek F. 2004b. Present status of radiocarbon calibration and comparison records based on Polynesian corals and Iberian Margin sediments. Radiocarbon 46:1189-1202.

Bard E, Ménot G, Rostek F, Licari L, Böning P, Edwards RL, Cheng H, Wang Y, Heaton TJ. 2013. Radiocarbon calibration/comparison records based on marine sediments from the Pakistan and Iberian margins. Radiocarbon 55(4): 1999-2019.

Bayliss A, Marshall P, Friedrich M, Dee M, Heaton TJ, Bollhanger S, Wacker L. 2020. The IntCal20 tree rings: an archaeological SWOT analysis. Radiocarbon 62. This issue.

Bauska TK, Baggenstos D, Brook EJ, Mix AC, Marcott SA, Petrenko VV, Schaefer H, Severinghaus JP, Lee JE. 2016. Carbon isotopes characterize rapid changes in atmospheric carbon dioxide during the last deglaciation. Proceedings of the National Academy of Sciences 113:3465-3470.

Beck JW, Richards DA, Edwards RL, Silverman BW, Smar PL, Donahue DJ, Herrera-Osterheld S, 
Burr GS, Calsoyas L, Jull AJT, Biddulph D. 2001. Extremely large variations of atmospheric ${ }^{14} \mathrm{C}$ concentration during the last glacial period. Science 292:2453-2458.

Berry SM, Carroll RJ, Ruppert D. 2002 Bayesian smoothing and regression splines for measurement error problems. Journal of the American Statistical Association 97(457):160-169. doi:10. 1198/016214502753479301.

Braziunas TF, Fung IY, Stuiver M. 1995. The preindustrial atmospheric ${ }^{14} \mathrm{CO}_{2}$ latitudinal gradient as related to exchanges among atmospheric, oceanic, and terrestrial reservoirs. Global Biogeochemical Cycles 9:565-584.

Bronk Ramsey C, Staff RA, Bryant CL, Brock F, Kitagawa $H$, van der Plicht J, Schlolaut G, Marshall MH, Brauer A, Lamb HF, Payne RL, Tarasov PE, Haraguchi T, Gotanda K, Yonenobu H, Yokoyama Y, Tada R, Nakagawa T. 2012. A complete terrestrial radiocarbon record for 11.2 to $52.8 \mathrm{kyr}$ BP. Science 338:370-374.

Bronk Ramsey C, Blaauw M, Kearney R, Staff RA. 2019. The importance of open access to chronological information: the IntChron initiative. Radiocarbon 61(5):1121-1131.

Bronk Ramsey C, Heaton TJ, Schlolaut G, Staff RA, Bryant CL, Brauer A, Lamb HF, Marshall MH, Nakagawa T. 2020. Reanalysis of the atmospheric radiocarbon calibration record from Lake Suigetsu, Japan. Radiocarbon 62. This issue. doi:10.1017/RDC.2020.18.

Buizert C, Cuffey K, Severinghaus J, Baggenstos D, Fudge T, Steig E, Markle B, Winstrup M, Rhodes RH, Brook EJ. 2015. The WAIS divide deep ice core WD2014 chronology-Part 1: methane synchronization (68-31 kaBP) and the gas age-ice age difference. Climate of the Past:11(2).

Büntgen U, Wacker L, Galván JD, Arnold S, Arseneault D, Baillie M, Beer J, Bernabei M, Bleicher N, Boswijk G, Bräuning A, Carrer M, Ljungqvist FC, Cherubini $\mathrm{P}$, Christl $\mathrm{M}$, Christie DA, Clark PW, Cook ER, D'Arrigo R, Davi N, Eggertsson Ó, Esper J, Fowler AM, Gedalof Ze, Gennaretti F, Grießinger J, Grissino-Mayer H, Grudd H, Gunnarson BE, Hantemirov R, Herzig F, Hessl A, Heussner K-U, Jull AJT, Kukarskih V, Kirdyanov A, Koláŕ T, Krusic PJ, Kyncl T, Lara A, LeQuesne C, Linderholm HW, Loader NJ, Luckman B, Miyake F, Myglan VS, Nicolussi K, Oppenheimer C, Palmer J, Panyushkina I, Pederson N, Rybníček M, Schweingruber FH, Seim A, Sigl M, Sidorova OC, Speer JH, Synal H-A, Tegel W, Treydte K, Villalba R, Wiles G, Wilson R, Winship LJ, Wunder J, Yang B, Young GHF. 2018. Tree rings reveal globally coherent signature of cosmogenic radiocarbon events in 774 and 993 CE. Nature Communications 9:3605.
Butzin M, Köhler P, Lohmann G. 2017. Marine radiocarbon reservoir age simulations for the past 50,000 years. Geophysical Research Letters 44(16):8473-8480. doi:10.1002/2017GL074688.

Butzin M, Heaton TJ, Köhler P, Lohmann G. 2020. A short note on marine reservoir age simulations used in IntCal20. Radiocarbon 62. This issue. doi:10.1017/RDC.2020.9.

Cain WF, Suess HE. 1976. Carbon-14 in tree rings. Journal of Geophysical Research-Oceans and Atmospheres 81:3688-3694.

Capano M, Miramont C, Guibal F, Kromer B, Tuna T, Fagault Y, Bard E. 2018. Wood ${ }^{14} \mathrm{C}$ dating with AixMICADAS: methods and application to tree-ring sequences from the Younger Dryas Event in the southern French Alps. Radiocarbon 60(1):51-74.

Capano M, Miramont C, Shindo L, Guibal F, Marschal C, Kromer B, Tuna T, Bard E. 2019. Onset of the Younger Dryas recorded with ${ }^{14} \mathrm{C}$ at annual resolution in French subfossil trees. Radiocarbon 62. This issue. doi:10.1017/RDC. 2019.116.

Channell JET, Harrison RJ, Lascu I, McCave IN, Hibbert FD, Austin WEN, 2016. Magnetic record of deglaciation using FORC-PCA, sortable-silt grain size, and magnetic excursion at $26 \mathrm{ka}$, from the Rockall Trough (NE Atlantic). Geochemistry, Geophysics, Geosystems 17: 1823-1841.

Cheng H, Sinha A, Cruz FW, Wang X, Edwards RL, d'Horta FM, Ribas CC, Vuille M, Stott LD, Auler AS. 2013. Climate change patterns in Amazonia and biodiversity. Nature Communications 4:1411.

Cheng H, Edwards RL, Sinha A, Spötl C, Yi L, Chen S, Kelly M, Kathayat G, Wang X, Li X. 2016. The Asian monsoon over the past 640,000 years and ice age terminations. Nature 534(7609):640.

Cheng H, Edwards RL, Southon J, Matsumoto K, Feinberg JM, Sinha A, Zhou W, Li H, Li X, $\mathrm{Xu}$ Y. 2018. Atmospheric ${ }^{14} \mathrm{C} /{ }^{12} \mathrm{C}$ changes during the last glacial period from Hulu Cave. Science 362(6420):1293-1297.

Cutler KB, Gray SC, Burr GS, Edwards RL, Taylor FW, Cabioch G, Beck JW, Cheng H, Moore J. 2004. Radiocarbon calibration to $50 \mathrm{kyr} \mathrm{BP}$ with paired ${ }^{14} \mathrm{C}$ and ${ }^{230} \mathrm{Th}$ dating of corals from Vanuatu and Papua New Guinea. Radiocarbon 46(3):1127-1160.

Darfeuil S, Ménot G, Giraud X, Rostek F, Tachikawa K, Garcia M, Bard É. 2016. Sea surface temperature reconstructions over the last $70 \mathrm{kyr}$ off Portugal: Biomarker data and regional modeling. Paleoceanography 31(1):40-65.

Dee MW, Brock F, Harris SA, Bronk Ramsey C, Shortland AJ, Higham TFG, Rowland JM. 2010. Investigating the likelihood of a reservoir offset in the radiocarbon record for ancient Egypt. Journal of Archaeological Science 37(4):687-693. 
Dellinger F, Kutschera W, Nicolussi K, Schießling P, Steier P, Wild EM. 2004. A ${ }^{14} \mathrm{C}$ calibration with AMS from 3500 to $3000 \mathrm{BC}$, derived from a new high-elevation stone-pine tree-ring chronology. Radiocarbon 46:969-978.

Durand N, Deschamps P, Bard E, Hamelin B, Camoin G, Thomas AL, Henderson GM, Yokoyama Y, Matsuzaki H. 2013. Comparison of ${ }^{14} \mathrm{C}$ and $\mathrm{U}-\mathrm{Th}$ ages in corals from IODP \#310 cores offshore Tahiti. Radiocarbon 55(4):1947-1974.

Fahrni SM, Southon J, Fuller BT, Park J, Friedrich M, Muscheler R, Wacker L, Taylor RE. 2020. Single-year German oak and Californian bristlecone pine ${ }^{14} \mathrm{C}$ data at the beginning of the Hallstatt plateau from $856 \mathrm{BC}$ to $626 \mathrm{BC}$. Radiocarbon 62. This issue. doi:10.1017/RDC. 2020.16.

Fairbanks RG, Mortlock RA, Chiu TC, Cao L, Kaplan A, Guilderson TP, Fairbanks TW, Bloom AL, Grootes PM, Nadeau MJ. 2005. Radiocarbon calibration curve spanning 0 to 50,000 years BP based on paired Th-230/U-234/ $\mathrm{U}-238$ and $\mathrm{C}-14$ dates on pristine corals. Quaternary Science Reviews 24(16-17): 1781-1796.

Fagault Y, Tuna T, Rostek F, Bard E. 2019. Radiocarbon dating small carbonate samples with the gas ion source of AixMICADAS. Nuclear Instruments and Methods in Physics Research B 455:276-283.

Fohlmeister J, Kromer B, Mangini A. 2011. The influence of soil organic matter age spectrum on the reconstruction of atmospheric ${ }^{14} \mathrm{C}$ levels via stalagmites. Radiocarbon 53(1):99-115.

Friedrich M, Remmele S, Kromer B, Hofmann J, Spurk M, Kaiser KF, Orcel C, Küppers M. 2004. The 12,460-year Hohenheim oak and pine tree-ring chronology from Central Europe: a unique annual record for radiocarbon calibration and palaeo-environment reconstructions. Radiocarbon 46(3):1111-1122.

Friedrich R, Kromer B, Sirocko F, Esper J, Lindauer S, Nievergelt D, Heussner KU, Westphal T. 2019. Annual ${ }^{14} \mathrm{C}$ tree-ring data around $400 \mathrm{AD}$ : midand high-latitude records. Radiocarbon 60(5): 1305-1316.

Friedrich R, Kromer B, Wacker L, Olsen J, Remmele, S, Lindauer S, Land, A, Pearson C. 2020. A new annual ${ }^{14} \mathrm{C}$ dataset for calibrating the Thera eruption. Radiocarbon 62. This issue. doi: 10 . 1017/RDC.2020.33.

Galbraith ED, Kwon EY, Bianchi D, Hain MP, Sarmiento JL. 2015. The impact of atmospheric $\mathrm{pCO}_{2}$ on carbon isotope ratios of the atmosphere and ocean. Global Biogeochemical Cycles 29:307-324.

Giaccio B, Hajdas I, Isaia R, Deino A, Nomade S. 2017. High-precision ${ }^{14} \mathrm{C}$ and ${ }^{40} \mathrm{Ar} /{ }^{39} \mathrm{Ar}$ dating of the Campanian Ignimbrite (Y-5) reconciles the time-scales of climatic-cultural processes at $40 \mathrm{ka}$. Scientific Reports 7.

Hamilton WD, Haselgrove C, Gosden C. 2015. The impact of Bayesian chronologies on the British Iron Age. World Archaeology 47(4): 642-660.

Haug GH, Hughen KA, Sigman DM, Peterson LC, Röhl U. 2001. Southward migration of the Intertropical Convergence Zone through the Holocene. Science 293(5533):1304-1308.

Heaton TJ, Bard E, Hughen KA. 2013. Elastic tiepointing-transferring chronologies between records via a Gaussian process. Radiocarbon 55(4):1975-1997.

Heaton TJ, Köhler P, Butzin M, Bard E, Reimer RW, Austin WEN, Bronk Ramsey C, Grootes PM, Hughen KA, Kromer B, Reimer PJ, Adkins JF, Burke A, Cook MS, Olsen J, Skinner LC. 2020a. Marine20 - the marine radiocarbon age calibration curve $(0-55,000$ cal BP $)$. Radiocarbon 62. This issue. doi:10.1017/RDC. 2020.68.

Heaton TJ, Blaauw M, Blackwell PG, Bronk Ramsey C, Reimer P, Scott EM. 2020b. The IntCal20 approach to radiocarbon calibration curve construction: a new methodology using Bayesian splines and errors-in-variables. Radiocarbon 62 . This issue. doi:10.1017/RDC.2020.46.

Hendy CH. 1971. The isotopic geochemistry of speleothems-I. The calculation of the effects of different modes of formation on the isotopic composition of speleothems and their applicability as palaeoclimatic indicators. Geochimica et Cosmochimica Acta 35(8): 801-824.

Hoffmann DL, Beck JW, Richards DA, Smart PL, Singarayer JS, Ketchmark T, Hawkesworth CJ. 2010. Towards radiocarbon calibration beyond $28 \mathrm{ka}$ using speleothems from the Bahamas. Earth and Planetary Science Letters 289:1-10.

Hogg A, McCormac F, Higham T, Baillie M, Palmer J. 2002. High-precision ${ }^{14} \mathrm{C}$ measurements of contemporaneous tree-ring dated wood from the British Isles and New Zealand: AD 1850-950. Radiocarbon 44(3):633-640.

Hogg A, Palmer J, Boswijk G, Reimer P, Brown D. 2009. Investigating the interhemispheric ${ }^{14} \mathrm{C}$ offset in the 1st millennium AD and assessment of laboratory bias and calibration errors. Radiocarbon 51(4):1177-1186.

Hogg A, Turney C, Palmer J, Cook E, Buckley B. 2013a. Is there any Evidence for Regional Atmospheric ${ }^{14} \mathrm{C}$ Offsets in the Southern Hemisphere? Radiocarbon 55:2029-2034.

Hogg, AG, Hua, Q, Blackwell, PG, Niu, M, Buck, CE, Guilderson TP, Heaton TJ, Palmer, JG, Reimer, PJ, Reimer, RW, Turney CSM, and Zimmerman, SRH. 2013b. SHCal13 Southern Hemisphere Calibration, 0-50,000 Years cal BP. Radiocarbon 55(4):1889-1903. 
Hogg A, Southon J, Turney C, Palmer J, Bronk Ramsey C, Fenwick P, Boswijk G, Büntgen U, Friedrich M, Helle G. 2016. Decadally resolved Lateglacial radiocarbon evidence from New Zealand kauri. Radiocarbon 58(4):709-733.

Hogg AG, Heaton TJ, Hua Q, Palmer JG, Turney CSM, Southon J, Bayliss A, Blackwell PG, Boswijk G, Bronk Ramsey C, Pearson C, Petchey F, Reimer P, Reimer R, Wacker L. 2020. SHCal20 Southern Hemisphere calibration, 0-55,000 years cal BP. Radiocarbon 62. This issue. doi:10.1017/RDC.2020.59.

Hua Q, Barbetti M, Zoppi U, Fink D, Watanasak M, Jacobsen GE. 2004. Radiocarbon in tropical tree rings during the Little Ice Age. Nuclear Instruments and Methods in Physics Research B 223-224:489-494.

Hua Q, Barbetti M. 2007. Influence of atmospheric circulation on regional ${ }^{14} \mathrm{CO}_{2}$ differences. Journal of Geophysical Research: Atmospheres 112(D19).

Hua Q, Barbetti M, Fink D, Kaiser KF, Friedrich M, Kromer B, Levchenko VA, Zoppi U, Smith AM, Bertuch F. 2009. Atmospheric ${ }^{14} \mathrm{C}$ variations derived from tree rings during the early Younger Dryas. Quaternary Science Reviews 28:2982-2990.

Hughen KA, Southon JA, Lehman, SJ, Bertrand, CJH, Turnbull, J. 2006. Marine-derived ${ }^{14} \mathrm{C}$ calibration and activity record for the past 50,000 years updated from the Cariaco Basin. Quaternary Science Reviews 25:3216-3227.

Hughen KA, Eglinton TI, Xu, L, Makou, M. 2004a. Abrupt tropical vegetation response to rapid climate changes. Science 304:1955-1959.

Hughen KA, Southon JR, Bertrand, C, Frantz, B, Zermeno, P. 2004b. Cariaco Basin calibration update: revisions to calendar and ${ }^{14} \mathrm{C}$ chronologies for Core PL07-58PC. Radiocarbon 46:1161-1188.

Hughen KA, Overpeck JT, Peterson LC, Trumbore S. 1996. Rapid climate changes in the tropical Atlantic region during the last deglaciation. Nature 380:51-54.

Hughen K, Heaton TJ. 2020. Updated Cariaco Basin ${ }^{14} \mathrm{C}$ calibration dataset from $0-60$ cal kyr BP. Radiocarbon 62. This issue. doi: 10.1017/RDC. 2020.53.

Ingram BL. 1998. Differences in radiocarbon age between shell and charcoal from a Holocene shellmound in Northern California. Quaternary Research 49(1):102-110.

Jansma E, Brewer PW, Zandhuis I. 2010. TRiDaS 1.1: The tree-ring data standard. Dendrochronologia 28:99-130.

Jansma E, van Lanen RJ, Brewer PW, Kramer R. 2012. The DCCD: A digital data infrastructure for tree-ring research. Dendrochronologia 30:249-251.

Jull AT, Panyushkina IP, Lange TE, Kukarskih VV, Myglan VS, Clark KJ, Salzer MW, Burr GS, Leavitt SW. 2014. Excursions in the ${ }^{14} \mathrm{C}$ record at AD 774-775 in tree rings from Russia and America. Geophysical Research Letters 41(8):3004-3010.

Jull AT, Panyushkina I, Miyake F, Masuda K, Nakamura T, Mitsutani T, Lange TE, Cruz RJ, Baisan C, Janovics R. 2018. More rapid ${ }^{14} \mathrm{C}$ excursions in the tree-ring record: $\mathrm{A}$ record of different kind of solar activity at about $800 \mathrm{BC}$ ? Radiocarbon 60(4):1237-1248.

Kaiser KF, Friedrich M, Miramont C, Kromer B, Sgier M, Schaub M, Boeren I, Remmele S, Talamo S, Guibal F, Sivan O. 2012. Challenging process to make the Lateglacial tree-ring chronologies from Europe absolute - an inventory. Quaternary Science Reviews 36: 78-90.

Kaufman DS, Abram NJ, Evans MN, Francus P, Goosse H, Linderholm HW, Loutre M-F, Martrat B, McGregor HV, Neukom R. 2018. Open-paleo-data implementation pilot-The PAGES 2k special issue. Climate of the Past 14:593-600.

Kong X, Wang Y, Wu J, Cheng H, Edwards R, Wang X. 2005. Complicated responses of stalagmite $\delta^{13} \mathrm{C}$ to climate change during the last glaciation from Hulu Cave, Nanjing, China. Science in China Series D: Earth Sciences 48:2174-2181.

Kromer B, Manning SW, Kuniholm PI, Newton MW, Spurk M, Levin I. 2001. Regional ${ }^{14} \mathrm{CO}_{2}$ gradients in the troposphere: magnitude, mechanisms and consequences: Science 294:2529-2532.

Kromer B, Friedrich M, Hughen KA, Kaiser F, Remmele S, Schaub M, Talamo S. 2004. Late Glacial ${ }^{14} \mathrm{C}$ ages from a floating 1382-ring pine chronology. Radiocarbon 46(3):1203-1209.

Kudsk SGK, Philippsen B, Baittinger C, FogtmannSchulz A, Knudsen M, Karoff CA, Olsen J. 2019. New single-year radiocarbon measurements based on Danish oak covering the periods AD 692-790 and 966-1057 AD. Radiocarbon 62. This issue. doi:10.1017/RDC.2019.107.

Kuitems M, van der Plicht J, Jansma E. 2020. Wood from the Netherlands around the time of the Santorini eruption dated by dendrochronology and radiocarbon. Radiocarbon 62. This issue. doi:10.1017/RDC.2020.23

Kutschera W, Bietak M, Wild EM, Bronk Ramsey C, Dee M, Golser R, Kopetzky K, Stadler P, Steier P, Thanheiser U. 2012. The chronology of Tell el-Daba: a crucial meeting point of ${ }^{14} \mathrm{C}$ dating, archaeology, and Egyptology in the 2nd millennium BC. Radiocarbon 54(3-4):407-422.

Laj C, Guillou, H, Kissel, CA. 2014. Dynamics of the earth magnetic field in the 10-75 kyr period comprising the Laschamp and Mono Lake excursions: New results from the French Chaîne des Puys in a global perspective. Earth and Planetary Science Letters 387:184-197.

Laj C, Kissel CA. 2015. An impending geomagnetic transition? Hints from the past. Frontiers in Earth Science 3:61. 
Lascu I, Feinberg JM, Dorale JA, Cheng H, Edwards RL. 2016. Age of the Laschamp excursion determined by U-Th dating of a speleothem geomagnetic record from North America. Geology 44:139-142.

Lechleitner FA, Baldini JU, Breitenbach SF, Fohlmeister J, McIntyre C, Goswami B, Jamieson RA, van der Voort TS, Prufer K, Marwan N. 2016. Hydrological and climatological controls on radiocarbon concentrations in a tropical stalagmite. Geochimica et Cosmochimica Acta 194:233-252.

Lisi CS, Pessenda LC, Tomazello M, Rozanski K. 2001. ${ }^{14} \mathrm{C}$ bomb effect in tree rings of tropical and subtropical species of Brazil: Tree-Ring Research 57:191-196.

Loader NJ, McCarroll D, Miles D, Young GH, Davies D, Bronk Ramsey C. 2019. Tree ring dating using oxygen isotopes: A master chronology for central England. Journal of Quaternary Science 34:475-490.

Manabe S, Stouffer RJ. 1995. Simulation of abrupt climate change induced by freshwater input to the North Atlantic Ocean. Nature 378:165-167.

Manning SW, Kromer B, Cremaschi M, Dee MW, Friedrich R, Griggs C, Hadden CS. 2020. Mediterranean radiocarbon offsets and calendar dates for prehistory. Science Advances 6: eaaz1096.

Manning SW, Höflmayer F, Moeller N, Dee MW, Bronk Ramsey C, Fleitmann D, Higham T, Kutschera W, Wild EM. 2014. Dating the Thera (Santorini) eruption: archaeological and scientific evidence supporting a high chronology. Antiquity 88(342):1164-1179.

Manning SW, Griggs C, Lorentzen B, Bronk Ramsey C, Chivall D, Jull AT, Lange TE. 2018. Fluctuating radiocarbon offsets observed in the southern Levant and implications for archaeological chronology debates. Proceedings of the National Academy of Sciences 115(24):6141-6146.

Marcott SA, Bauska TK, Buizert C, Steig EJ, Rosen JL, Cuffey KM, Fudge T, Severinghaus JP, Ahn J, Kalk ML. 2014. Centennial-scale changes in the global carbon cycle during the last deglaciation. Nature 514:616.

Markowska M, Fohlmeister J, Treble PC, Baker A, Andersen MS, Hua Q. 2019. Modelling the ${ }^{14} \mathrm{C}$ bomb-pulse in young speleothems using a soil carbon continuum model. Geochimica et Cosmochimica Acta 261:342-367.

Marsh EJ, Bruno MC, Fritz SC, Baker P, Capriles JM, Hastorf CA. 2018. IntCal, SHCal, or a mixed curve? Choosing a ${ }^{14} \mathrm{C}$ calibration curve for archaeological and paleoenvironmental records from tropical South America. Radiocarbon 60:925-940.

McCormac FG, Hogg AG, Higham TFG, Lynch, Stieglitz J, Broecker WS, Baillie MGL, Palmer J, Xiong L, Pilcher JR, Brown D, Hoper ST.
1998. Temporal variation in the interhemispheric ${ }^{14} \mathrm{C}$ offset. Geophysical Research Letters 25(9):1321-1324.

McCormac FG, Bayliss A, Baillie MGL, Brown DM. 2004. Radiocarbon calibration in the AngloSaxon period: AD 495-725. Radiocarbon 46:1123-1125.

McCormac FG, Bayliss A, Brown DM, Reimer PJ, Thompson MM. 2008. Extended radiocarbon calibration in the Anglo-Saxon period, AD 395-485 and AD 735-805. Radiocarbon 50(1): 11-17.

Mekhaldi F, Muscheler R, Adolphi F, Aldahan A, Beer J, McConnell JR, Possnert G, Sigl M, Svensson A, Synal H-A. 2015. Multiradionuclide evidence for the solar origin of the cosmic-ray events of AD 774/5 and 993/4: Nature Communications 6:8611.

Miyake F, Nagaya K, Masuda K, Nakamura T. 2012. A signature of cosmic-ray increase in AD 774-775 from tree rings in Japan. Nature 486(7402):240-242.

Miyake F, Masuda K, Nakamura T. 2013. Another rapid event in the carbon-14 content of tree rings. Nature Communications 4.

Miyake, F, Suzuki, A, Masuda, K, Horiuchi, K, Motoyama, H, Matsuzaki, H, Motizuki, Y, Takahashi, K, Nakai, Y. 2015. Cosmic ray event of AD 774-775 shown in quasi-annual ${ }^{10} \mathrm{Be}$ data from the Antarctic Dome Fuji ice core. Geophysical Research Letters 42:84-89.

Miyake F, Jull AJT, Panyushkina IP, Wacker L, Salzer M, Baisan $\mathrm{CH}$, Lange $\mathrm{T}$, Cruz R, Masuda K, Nakamura T. 2017a. Large ${ }^{14} \mathrm{C}$ excursion in $5480 \mathrm{BC}$ indicates an abnormal sun in the mid-Holocene. Proceedings of the National Academy of Sciences 114(5):881-884.

Miyake F, Masuda K, Nakamura T, Kimura K, Hakozaki M, Jull AJT, Lange TE, Cruz R, Panyushkina IP, Baisan C, Salzer MW. 2017b. Search for annual ${ }^{14} \mathrm{C}$ excursions in the Ppast. Radiocarbon 59(2):315-320.

Molnos S, Mamdouh T, Petri S, Nocke T, Weinkauf T, Coumou D. 2017. A network-based detection scheme for the jet stream core. Earth System Dynamics 8:75-89.

Monge Soares AM. 1993. The ${ }^{14} \mathrm{C}$ content of marine shells: Evidence for variability in coastal upwelling off Portugal during the Holocene. Isotope Techniques in the Study of Past and Current Environmental Changes in the Hydrosphere and Atmosphere. Vienna: International Atomic Energy Agency. p 471-485.

Muscheler R, Beer J, Kubik PW, Synal HA. 2005. Geomagnetic field intensity during the last 60,000 years based on ${ }^{10} \mathrm{Be}$ and ${ }^{36} \mathrm{Cl}$ from the Summit ice cores and ${ }^{14} \mathrm{C}$. Quaternary Science Reviews 24:1849-1860.

Muscheler R, Adolphi F, Heaton TJ, Bronk Ramsey C, Svensson A, van der Plicht J, Reimer PJ. 2020. Testing and improving the ${ }^{14} \mathrm{C}$ calibration curve 
with independent records. Radiocarbon 62 . This issue. doi:10.1017/RDC.2020.54.

Nakai W, Okada N, Sano M, Nakatsuka T. 2018. Sample preparation of ring-less tropical trees for $\delta^{18} \mathrm{O}$ measurement in isotope dendrochronology. Tropics 27(2):49-58.

Nakamura T, Miyahara H, Masuda K, Menjo H, Kuwana K, Kimura K, Okuno M, Minami M, Oda H, Rakowski A, Ohta T, Ikeda A, Niu E. 2007. High precision ${ }^{14} \mathrm{C}$ measurements and wiggle-match dating of tree rings at Nagoya University. Nuclear Instruments and Methods in Physics Research B 259:408-413.

Niu M, Heaton TJ, Blackwell PG, Buck CE. 2013. The Bayesian approach to radiocarbon calibration curve estimation: the IntCal13, Marine13, and SHCal13 methodologies. Radiocarbon 55(4):1905-1922.

Noronha, AL, Johnson, KR, Southon, JR, Hu, C, Ruan, J, McCabe-Glynn, S. 2015. Radiocarbon evidence for decomposition of aged organic matter in the vadose zone as the main source of speleothem carbon. Quaternary Science Reviews 127:37-47.

North Greenland Ice Core Project members. 2004. High-resolution record of Northern Hemisphere climate extending into the last interglacial period. Nature 431(7005): 147.

O'Hare P, Mekhaldi F, Adolphi F, Raisbeck G, Aldahan A, Anderberg E, Beer J, Christl M, Fahrni S, Synal H-A. 2019. Multiradionuclide evidence for an extreme solar proton event around 2,610 BP ( $660 \mathrm{BC})$. Proceedings of the National Academy of Sciences 116:5961-5966.

Oster JL, Montanez IP, Guilderson TP, Sharp WD, Banner JL. 2010. Modeling speleothem $\delta^{13} \mathrm{C}$ variability in a central Sierra Nevada cave using ${ }^{14} \mathrm{C}$ and ${ }^{87} \mathrm{Sr} /{ }^{86} \mathrm{Sr}$. Geochimica et Cosmochimica Acta 74:5228-5242.

Park, J, Southon, J, Fahrni, S, Creasman, PP, Mewaldt, R., 2017. Relationship between solar activity and $\Delta{ }^{14} \mathrm{C}$ peaks in AD 775, AD 994, and 660 BC. Radiocarbon 59:1147-1156.

Pearson CL, Brewer PW, Brown D, Heaton TJ, Hodgins GW, Jull AT, Lange T, Salzer MW. 2018. Annual radiocarbon record indicates 16th century BCE date for the Thera eruption. Science Advances 4(8):eaar8241.

Pearson CL, Wacker L, Bayliss A, Brown DM, Salzer M, Brewer PW, Bollhalder S, Boswijk G, Hodgins GWL. 2020. Annual variation in atmospheric ${ }^{14} \mathrm{C}$ between $1700 \mathrm{BC}$ and $1480 \mathrm{BC}$. Radiocarbon 62. This issue. doi:10.1017/RDC.2020.14.

Peterson LC, Haug GH, Hughen KA, Röhl U. 2000. Rapid changes in the hydrologic cycle of the tropical Atlantic during the last glacial. Science 290:1947-1951.

Pilcher JR. 1995. Biological considerations in the interpretation of stable isotope ratios in oak tree-rings: Paläoklimaforschung 15:157-161.
Rasmussen SO, Bigler M, Blockley SP, Blunier T, Buchardt SL, Clausen HB, Cvijanovic I, Dahl-Jensen D, Johnsen SJ, Fischer H, Gkinis V, Guillevic M, Hoek WZ, Lowe JJ, Pedro JB, Popp T, Seierstad IK, Steffensen JP, Svensson AM, Vallelonga P, Vinther BM, Walker MJC, Wheatley JJ, Winstrup M. 2014. A stratigraphic framework for abrupt climatic changes during the Last Glacial period based on three synchronized Greenland ice-core records: refining and extending the INTIMATE event stratigraphy. Quaternary Science Reviews 106:14-28.

Reimer PJ, Baillie MGL, Bard E, Bayliss A, Beck JW, Bertrand CJH, Blackwell PG, Buck CE, Burr GS, Cutler KB, Damon PE, Edwards RL, Fairbanks RG, Friedrich M, Guilderson TP, Hogg AG, Hughen KA, Kromer B, McCormac G, Manning S, Bronk Ramsey C, Reimer RW, Remmele S, Southon JR, Stuiver M, Talamo S, Taylor FW, van der Plicht J, Weyhenmeyer CE. 2004. IntCal04 terrestrial radiocarbon age calibration, 0-26 cal kyr BP. Radiocarbon 46(3):1029-1058.

Reimer PJ, Baillie MGL, Bard E, Bayliss A, Beck JW, Blackwell PG, Bronk Ramsey C, Buck CE, Burr GS, Edwards RL, Friedrich M, Grootes PM, Guilderson TP, Hajdas I, Heaton TJ, Hogg AG, Hughen KA, Kaiser KF, Kromer B, McCormac FG, Manning SW, Reimer RW, Richards DA, Southon JR, Talamo S, Turney CSM, van der Plicht J, Weyhenmeyer CE. 2009. IntCa109 and Marine09 radiocarbon age calibration curves, 0-50,000 years cal BP. Radiocarbon 51(4):1111-1150.

Reimer, PJ, Bard, E, Bayliss, A, Beck, JW, Blackwell, PG, Bronk Ramsey, C, Brown, DM, Buck, CE, Edwards, RL, Friedrich, M. 2013a. Selection and treatment of data for radiocarbon calibration: an update to the International Calibration (IntCal) criteria. Radiocarbon 55: 1923-1945.

Reimer PJ, Bard E, Bayliss A, Beck JW, Blackwell PG, Bronk Ramsey C, Buck CE, Cheng H, Edwards RL, Friedrich M, Grootes PM, Guilderson TP, Haflidason H, Hajdas I, Hatté C, Heaton TJ, Hoffmann DL, Hogg AG, Hughen KA, Kaiser KF, Kromer B, Manning SW, Niu M, Reimer RW, Richards DA, Scott EM, Southon JR, Staff RA, Turney CSM, van der Plicht J. 2013b. IntCal13 and Marine13 radiocarbon age calibration curves $0-50,000$ years cal BP. Radiocarbon 55(4):1869-1887.

Reinig F, Nievergelt D, Esper J, Friedrich M, Helle G, Hellmann L, Kromer B, Morganti S, Pauly M, Sookdeo A, Tegel W, Treydte K, Verstege A, Wacker L, Büntgen U. 2018. New tree-ring evidence for the Late Glacial period from the northern pre-Alps in eastern Switzerland. Quaternary Science Reviews 186: 215-224. 
Reinig F, Sookdeo A, Esper J, Friedrich M, Guidobaldi G, Helle G, Kromer B, Nievergelt D, Pauly M, Tegel W, Treydte K, Wacker L, Büntgen U. 2020. Illuminating IntCal during the Younger Dryas. Radiocarbon 62. This issue. doi:10.1017/RDC.2020.15.

Rind D, Peteet D, Broecker WS, McIntyre A, Ruddiman W. 1986. The impact of cold North Atlantic sea surface temperatures on climate: implications for the Younger Dryas cooling (11-10k). Climate Dynamics 1:33.

Rudzka D, McDermott F, Baldini LM, Fleitmann D, Moreno A, Stoll H. 2011. The coupled $\delta^{13} \mathrm{C}-$ radiocarbon systematics of three Late Glacial/ early Holocene speleothems; insights into soil and cave processes at climatic transitions. Geochimica et Cosmochimica Acta 75:4321-4339.

Santos GM, Linares R, Lisi CS, Tomazello Filho M. 2015. Annual growth rings in a sample of Paraná pine (Araucaria angustifolia): Toward improving the ${ }^{14} \mathrm{C}$ calibration curve for the Southern Hemisphere. Quaternary Geochronology 25:96-103.

Sarnthein M, Winn K, Jung SJ, Duplessy JC, Labeyrie L, Erlenkeuser H, Ganssen G. 1994. Changes in east Atlantic deepwater circulation over the last 30,000 years: Eight time slice reconstructions. Paleoceanography 9:209-267.

Schaub M, Kaiser KF, Frank DC, Büntgen U, Kromer B, Talamo S. 2008. Environmental change during the Allerod and Younger Dryas reconstructed from Swiss tree-ring data. Boreas 37(1):74-86.

Schlolaut G, Staff RA, Brauer A, Lamb HF, Marshall MH, Bronk Ramsey C, Nakagawa T. 2018. An extended and revised Lake Suigetsu varve chronology from $\sim 50$ to $\sim 10 \mathrm{ka}$ BP based on detailed sediment micro-facies analyses. Quaternary Science Reviews 200:351-366.

Schneider T, Bischoff T, Haug GH. 2014. Migrations and dynamics of the Intertropical Convergence Zone. Nature 513:45-53.

Scott EM, Naysmith P, Cook GT. 2017a. Why do we need ${ }^{14} \mathrm{C}$ inter-comparisons?: The Glasgow $-{ }^{14} \mathrm{C}$ inter-comparison series, a reflection over 30 years. Quaternary Geochronology 43:72-82.

Scott EM, Naysmith P, Cook GT. 2017b. Should archaeologists care about ${ }^{14} \mathrm{C}$ intercomparisons? Why? A summary report on SIRI. Radiocarbon 59(5):1589-1596.

Sigl M, Fudge TJ, Winstrup M, Cole-Dai J, Ferris D, McConnell JR, Taylor KC, Welten KC, Woodruff TE, Adolphi F, Bisiaux M, Brook EJ, Buizert C, Caffee MW, Dunbar NW, Edwards R, Geng L, Iverson N, Koffman B, Layman L, Maselli OJ, McGwire K, Muscheler R, Nishiizumi K, Pasteris DR, Rhodes RH, Sowers TA. 2016. The WAIS Divide deep ice core WD2014 chronology - Part 2: Annuallayer counting $(0-31 \mathrm{ka}$ BP). Climate of the Past 12:769-786.
Skinner L, Primeau F, Freeman E, de la Fuente M, Goodwin P, Gottschalk J, Huang E, McCave I, Noble T, Scrivner A. 2017. Radiocarbon constraints on the glacial ocean circulation and its impact on atmospheric $\mathrm{CO}_{2}$. Nature Communications 8:16010.

Sookdeo A, Kromer B, Buentgen U, Friedrich M, Friedrich R, Helle G, Pauly M, Nievergelt D, Reinig F, Treydte K, Synal HA, Wacker, L. 2019. Quality Dating: A well-defined protocol implemented at ETH for high-precision ${ }^{14} \mathrm{C}$ dates tested on Late Glacial wood. Radiocarbon 62. This issue. doi:10.1017/RDC.2019. 132.

Southon J, Noronha AL, Cheng H, Edwards RL, Wang YJ. 2012. A high-resolution record of atmospheric ${ }^{14} \mathrm{C}$ based on Hulu Cave speleothem H82. Quaternary Science Reviews 33:32-41.

Stern JV, Lisiecki LE. 2013. North Atlantic circulation and reservoir age changes over the past 41,000 years. Geophysical Research Letters 40:3693-3697.

Stohl A, Bonasoni P, Cristofanelli P, Collins W, Feichter J, Frank A, Forster C, Gerasopoulos E, Gäggeler H, James P, Kentarchos T, KrompKolb H, Krüger B, Land C, Meloen J, Papayannis A, Priller A, Seibert P, Sprenger M, Roelofs GJ, Scheel HE, Schnabel C, Siegmund P, Tobler L, Trickl T, Wernli H, Wirth V, Zanis P, Zerefos CA. 2003. Stratosphere-troposphere exchange: A review, and what we have learned from STACCATO. Journal of Geophysical Research: Atmospheres 108(D12).

Stuiver M, Kromer B, Becker B, Ferguson CW. 1986. Radiocarbon age calibration back to 13,300 years $\mathrm{BP}$ and the ${ }^{14} \mathrm{C}$ age matching of the German oak and United-States bristlecone-pine chronologies. Radiocarbon 28(2B):969-979.

Stuiver M, Braziunas TF. 1998. Anthropogenic and solar components of hemispheric ${ }^{14} \mathrm{C}$. Geophysical Research Letters 25(3):329-332.

Stuiver M, Reimer PJ, Bard E, Beck JW, Burr GS, Hughen KA, Kromer B, McCormac G, Van der Plicht J, Spurk M. 1998a. INTCAL98 radiocarbon age calibration, 24,000-0 cal BP. Radiocarbon 40(3):1041-1083.

Stuiver M, Reimer PJ, Braziunas TF. 1998b. Highprecision radiocarbon age calibration for terrestrial and marine samples. Radiocarbon 40:1127-1151.

Svarva H, Grootes P, Seiler M, Stene S, Thun T, Værnes E, Nadeau M. 2019. The 1953-1965 rise in atmospheric bomb ${ }^{14} \mathrm{C}$ in central Norway. Radiocarbon 61(6):1765-1774.

Svensson A, Andersen KK, Bigler M, Clausen HB, Dahl-Jensen D, Davies SM, Johnsen SJ, Muscheler R, Parrenin F, Rasmussen SO, Roethlisberger R, Seierstad I, Steffensen JP, Vinther BM. 2008. A 60000 year Greenland stratigraphic ice core chronology: Climate of the Past 4:47-57. 
Tans PP, de Jong AFM, Mook WG. 1979. Natural atmospheric ${ }^{14} \mathrm{C}$ variation and the Suess effect. Nature 280:826-827

Turney CSM, Fifield LK, Hogg AG, Palmer JG, Hughen K, Baillie MGL, Galbraith R, Ogden J, Lorrey A, Tims SG, Jones RT. 2010. The potential of New Zealand kauri (Agathis australis) for testing the synchronicity of abrupt climate change during the Last Glacial Interval (60,000-11,700 years ago). Quaternary Science Reviews 29(27):3677-3682.

Turney CSM, Palmer J, Hogg A, Fogwill CJ, Jones R, Ramsey C, Fenwick P, Grierson P, Wilmshurst J, O'Donnell A, Thomas Z, Lipson M. 2016a. Multi-decadal variations in Southern Hemisphere atmospheric ${ }^{14} \mathrm{C}$ : Evidence against a Southern Ocean sink during the Little Ice Age $\mathrm{CO}_{2}$ anomaly. Global Biogeochemical Cycles 30: 211-218.

Turney CS, Palmer J, Bronk Ramsey C, Adolphi F, Muscheler R, Hughen KA, Staff RA, Jones RT, Thomas ZA, Fogwill CJ. 2016b. High-precision dating and correlation of ice, marine and terrestrial sequences spanning Heinrich Event 3: Testing mechanisms of interhemispheric change using New Zealand ancient kauri (Agathis australis). Quaternary Science Reviews 137: 126-134.

Tyers C, Jansma E. 2011. TRiCYCLE: a universal conversion tool for digital tree-ring data. TreeRing Research 67:135-145.

Usoskin IG, Kromer B, Ludlow F, Beer J, Friedrich M, Kovaltsov GA, Solanki SK, Wacker L. 2013. The AD 775 cosmic event revisited: The Sun is to blame. Astronomy \& Astrophysics 552:L3. doi:10.1051/0004-6361/201321080.

van der Plicht J, Jansma E, Kars H. 1995. The "Amsterdam Castle": A case study of wiggle matching and the proper calibration curve. Radiocarbon 37(3):965-968.

van der Plicht J, Bronk Ramsey C, Heaton T, Scott EM, Talamo S. 2020. Recent developments in calibration for archaeological and environmental terrestrial samples. Radiocarbon 62. This issue. doi:10.1017/RDC.2020.22.
Voelker AHL, Sarnthein M, Grootes PM, Erlenkeuser H, Laj C, Mazaud A, Nadeau MJ, Schleicher M. 1998. Correlation of marine ${ }^{14} \mathrm{C}$ ages from the Nordic Seas with the GISP2 isotope record: Implications for ${ }^{14} \mathrm{C}$ calibration beyond $25 \mathrm{ka}$ BP. Radiocarbon 40(1):517-534.

Wacker L, Guttler D, Goll J, Hurni JP, Synal HA, Walti N. 2014. Radiocarbon dating to a single year by means of rapid atmospheric ${ }^{14} \mathrm{C}$ changes. Radiocarbon 56:573-579

Wacker L, Scott EM, Bayliss A, Brown D, Bard E, Bollhalder S, Friedrich M, Capano M, Cherkinsky A, Chivall D, Culleton BJ, Dee MW, Friedrich R, Hodgins GWL, Hogg A, Kennett DJ, Knowles TDJ, Kuitems M, Lange TE, Miyake F, Nadeau M-J, Nakamura T, Naysmith JP, Olsen J, Omori T, Petchey F, Philippsen B, Bronk Ramsey C, Prasad GVR, Seiler M, Southon J, Staff R, Tuna T. 2020. Findings from an in-depth annual tree-ring radiocarbon intercomparison. Radiocarbon 62. This issue. doi:10.1017/RDC.2020.49.

Waelbroeck C, Lougheed BC, Vazquez Riveiros N, Missiaen L, Pedro J, Dokken T, Hajdas I, Wacker L, Abbott P, Dumoulin J-P, Thil F, Eynaud F, Rossignol L, Fersi W, Albuquerque AL, Arz H, Austin WEN, Came R, Carlson AE, Collins JA, Dennielou B, Desprat S, Dickson A, Elliot M, Farmer C, Giraudeau J, Gottschalk J, Henderiks J, Hughen K, Jung S, Knutz P, Lebreiro S, Lund DC, Lynch-Stieglitz J, Malaizé B, Marchitto T, Martínez-Méndez G, Mollenhauer G, Naughton F, Nave S, Nürnberg D, Oppo D, Peck V, Peeters FJC, Penaud A, Portilho-Ramos RdC, Repschläger J, Roberts J, Rühlemann C, Salgueiro E, Sanchez Goni MF, Schönfeld J, Scussolini P, Skinner LC, Skonieczny C, Thornalley D, Toucanne S, Rooij DV, Vidal L, Voelker AHL, Wary M, Weldeab S, Ziegler M. 2019. Consistently dated Atlantic sediment cores over the last 40 thousand years. Scientific Data 6:165.

Wang YJ, Cheng H, Edwards RL, An ZS, Wu JY, Shen CC, Dorale JA. 2001. A high-resolution absolutedated Late Pleistocene monsoon record from Hulu Cave, China. Science 294:2345-2348. 